\title{
Crosswalking National Wetland Inventory attributes to hydrogeomorphic functions and vegetation communities: a pilot study in the Gallatin Valley, Montana
}

Prepared for:

The Montana Department of Environmental Quality and

The United States Environmental Protection Agency

By:

Linda Vance, Gregory M. Kudray and Stephen V. Cooper

Montana Natural Heritage Program

Natural Resource Information System

Montana State Library

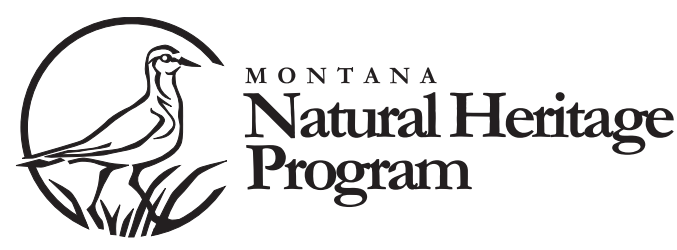





\section{Crosswalking National Wetland Inventory attributes to hydrogeomorphic functions and vegetation communities: a pilot study in the Gallatin Valley, Montana}

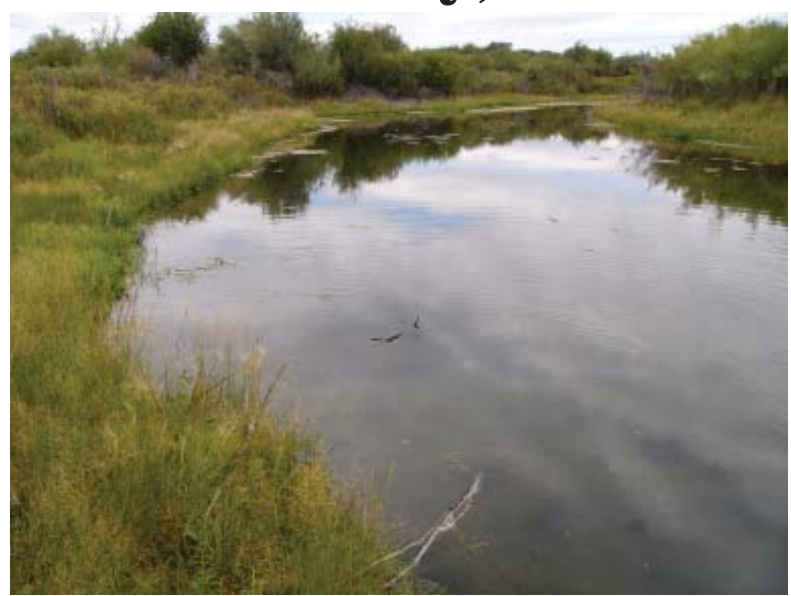

Prepared for:

The Montana Department of Environmental Quality and

The United States Environmental Protection Agency

Agreement Number:

205003

By:

Linda Vance, Gregory M. Kudray and Stephen V. Cooper
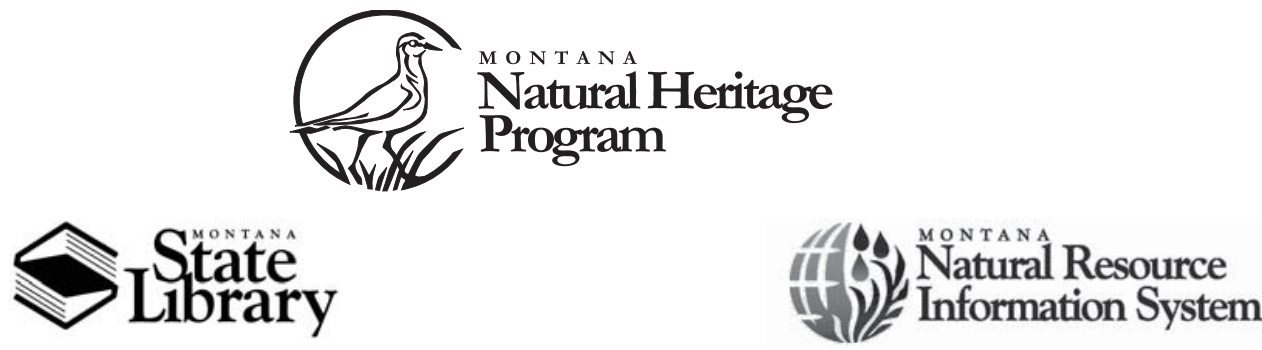

(C) 2006 Montana Natural Heritage Program

P.O. Box 201800 • 1515 East Sixth Avenue • Helena, MT 59620-1800 • 406-444-5354 
This document should be cited as follows:

Vance, Linda, Kudray, Gregory M. and Stephen V. Cooper. 2006. Crosswalking National

Wetland Inventory attributes to hydrogeomorphic functions and vegetation communities: a pilot study in the Gallatin Valley, Montana. Report to The Montana Department of Environmental Quality and The United States Environmental Protection Agency. Montana Natural Heritage Program, Helena, Montana 37 pp. plus appendices. 


\section{Executive Summary}

The Wetland and Riparian Mapping Center of the Montana Natural Heritage Program has recently begun new National Wetland Inventory (NWI) mapping for Montana. The present study was a pilot project to investigate ways to enhance the new mapping through additional classifications and modifiers. Specifically, our goals were to:

- Evaluate GIS-based approaches to Hydrogeomorphic (HGM) classification and profiling;

- Conduct an HGM functional assessment of the Gallatin Valley study area based on these classifications and profiles;

- Establish a crosswalk between NWI classifications, HGM classifications, and vegetation associations;

- Determine whether these additional classifications and associations could be efficiently linked with the National Wetland Inventory in future mapping.

Using existing NWI and geospatial data for soils, elevation, and hydrology, we developed a dichotomous key that could assign HGM classes to approximately $85 \%$ of the wetland polygons in the study area with $90 \%$ accuracy, as determined by visual inspection of the wetlands on 1-meter color imagery. The remaining wetland polygons were classified manually. We used a total of 32 HGM classifications, 17 for unaltered wetlands and 15 for altered wetlands. Nearly $85 \%$ of the wetland acreage in the study area is classified as Lotic. Lotic wetland acreage is concentrated in the Gallatin River-Gallatin Gateway (47\%) and Lower East Gallatin (25\%) watersheds, which contain the main Gallatin River and East Gallatin River channels. Smaller proportions are found in the Smith Creek (10\%) and Hyalite Creek (9\%) watersheds. Terrene wetland acreage is most plentiful in the Lower East Gallatin (41\%) and Smith Creek (27\%) watersheds. In the study area as a whole, NWI mapping from the 1980s shows less than $8 \%$ of the total wetland acreage as being directly altered. However, when wetland numbers are considered, almost $17 \%$ of wetlands were altered in some way. Although $85 \%$ of all the wetland acreage in the study area is Lotic, $72 \%$ of the altered wetland acreage is Terrene.

We used Principal Components Analysis to separate the 5th code HUCs into impact categories, evaluating road density, land cover, population density, septic density, average parcel size, percentage of private land ownership, percentage of public ownership and easements, and percentage of public land survey sections with one or more noxious weeds. The watersheds with the highest impact rankings were the Lower East Gallatin, Hyalite Creek, and the Upper East Gallatin. Together, these watersheds hold $87 \%$ of Terrene Interfluve Basin wetlands, $71 \%$ of Terrene Interfluve Flat wetlands, and 33\% of Terrene Basin wetlands. Because these types of wetlands have high function ratings for nutrient cycling, sediment trapping, aquatic and terrestrial habitat, and wetland biodiversity, we consider those functions to be at risk both within those watersheds and across the study area as a whole. Similarly, those three watersheds contain almost $40 \%$ of Lotic River Lower Gradient Floodplain wetlands, 36\% of Lotic River Lower Gradient Fringe Wetlands, and 39\% of Lotic Stream Lower Gradient Floodplain wetlands. Because these wetland types exist in other, somewhat less impacted watersheds (notably the Gallatin River-Gallatin Gateway and Lower Gallatin), their specific functions (surface water detention, stream maintenance, and plant community maintenance) are at least moderately at risk in the study area. Furthermore, because these Lotic types, like the Terrene types, also have high function ratings for sediment trapping and aquatic/terrestrial habitat, those functions may be especially compromised in these three watersheds.

From our field-based surveys and the GIS, we linked National Vegetation Classification System vegetation associations, Montana riparian types, and HGM-derived ecological functions to NWI types in the Gallatin Valley, so users could relate NWI classifications to detailed information useful for planning and management. These associations are complex. A specific NWI type typically encompasses several vegetation associations, but 
the relationship is usually understandable if past disturbances and regional environmental conditions are considered. NWI associations with HGM modifiers and ecological functions are similarly complex with a one-to-many relationship common.

We recommend that mapping in new areas continues to associate vegetation types with USFWS types, since the comprehensive, readily available information about these vegetation types will help those seeking to better understand or manage wetlands. Despite our success with a
GIS approach to adding HGM attributes to NWI types, we have not evaluated it beyond the study area, and therefore cannot say whether it offers a cost and time savings over individually classifying each polygon by hand. However, we recommend linking functions to NWI types continues in some form. Wetlands are valued (and regulated) because of their functions and associated values; connecting mapping with functions will aid wetland mitigation, restoration, conservation, and management. 


\section{ACKNOWLeDgements}

This project would not have been possible without the dynamic leadership of Lynda Saul, MT Department of Environmental Quality, in promoting wetland science and conservation. We also acknowledge Montana's Wetland Council in recognizing the need for a new National Wetlands Inventory in Montana. Tammy Crone of the Gallatin Valley Local Water Quality District was very helpful in contacting private landowners for access. Erin Farris, an intern at the MT Department of Environmental Quality, also assisted in landowner contact and other project support. Coburn Currier, of the Montana Natural Heritage Program, took on the task of formatting and publishing the report. We extend our thanks to all these individuals, but remind the reader any errors or omissions in the report are entirely the responsibility of the authors. 


\section{Table of Contents}

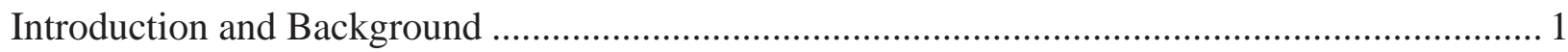

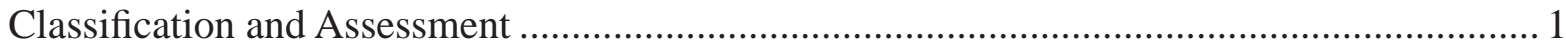

Crosswalk between NWI Classifications, HGM Classifications, and Vegetation

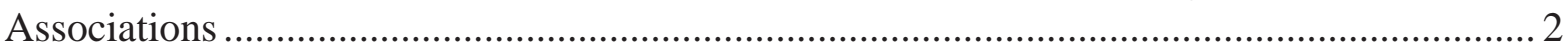

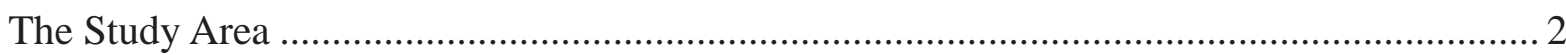

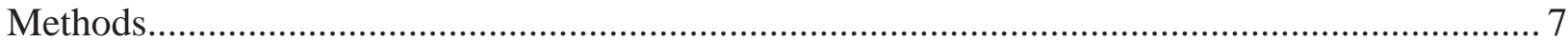

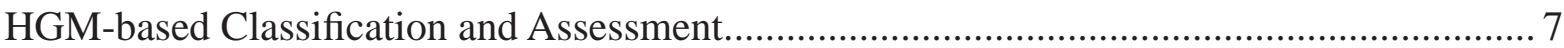

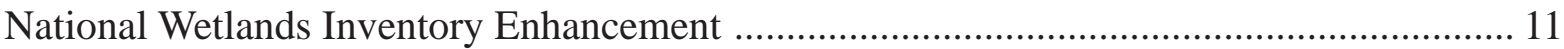

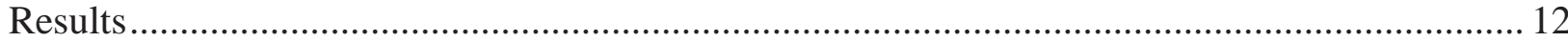

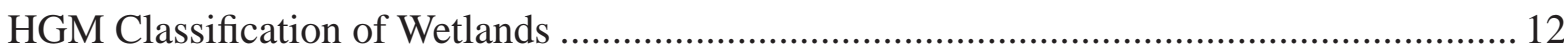

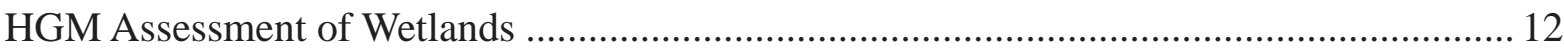

Evaluation of the Classification and Assessment Methodology …………………………......... 20

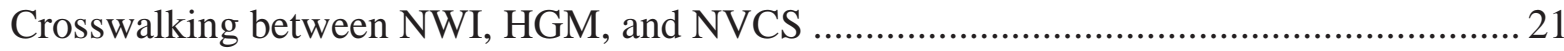

Guide to National Wetlands Inventory Types and Functions.................................................... 22

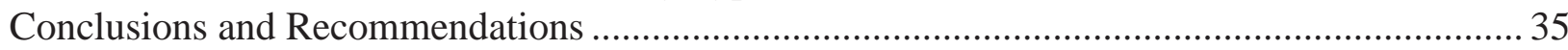

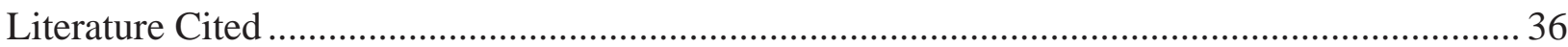

Appendix A. Dichotomous key for GIS-based Assignment of HGM Classifications to NWI Wetlands in the Gallatin Valley

Appendix B. NWI and HGM Codes and Descriptions Used in This Report

\section{List OF FigurES}

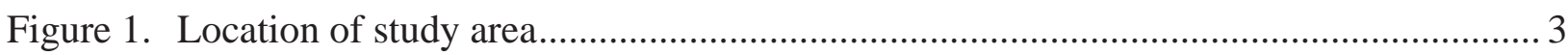

Figure 2. Mapped wetlands, Gallatin Valley ……………...................................................... 5

Figure 3. Public and private ownership, Gallatin Valley …………….......................................... 6

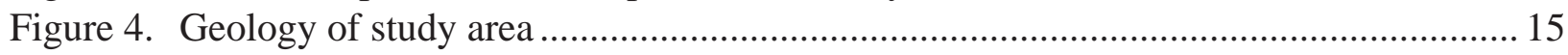

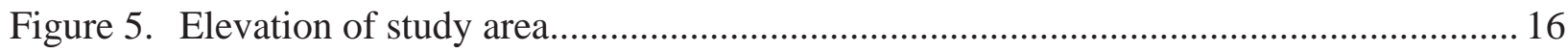

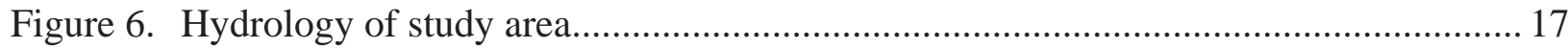

\section{List OF TABLES}

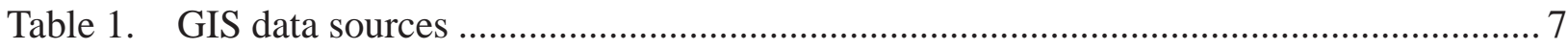

Table 2. HGM terms and descriptions used in this study ......................................................... 8

Table 3. Unaltered wetland acreage in the study area, by HGM class ....................................... 13

Table 4. Altered wetland acreage in the study area, by HGM class ............................................ 14

Table 5. Impacts by 5th-code HUCs in study area ................................................................... 19

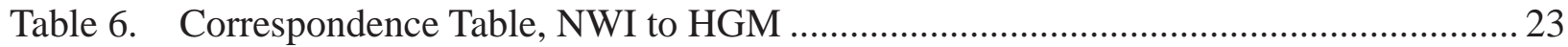

Table 7. Typical HGM types associated with PAB/PUB wetlands................................................. 25

Table 8. Functions associated with PAB/PUB wetlands............................................................. 25

Table 9. Typical HGM types associated with PEM wetlands..................................................... 27

Table 10. Functions associated with PEM wetlands................................................................... 27

Table 11. Typical HGM types associated with PSS wetlands ....................................................... 30 


\section{List OF TABLEs (CONTINUED)}

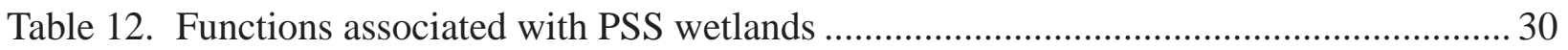

Table 13. Typical HGM types associated with PFO wetlands................................................. 32

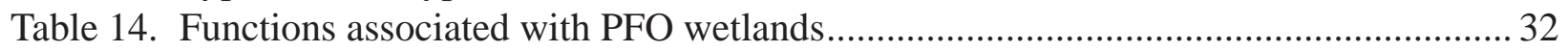

Table 15. Typical HGM types associated with R2US wetlands ........................................... 34

Table 16. Functions associated with R2US wetlands ........................................................ 34 



\section{INTRODUCTION AND BACKGROUND}

Wetlands provide numerous habitat and economic benefits, and are key factors in flood reduction, groundwater recharge, and biodiversity maintenance (Brinson et al. 1981, Keddy 2000). The scale and importance of wetland values are disproportionate to the physical extent of wetlands on the landscape, especially in a semiarid western state such as Montana (Finch and Ruggiero 1993, Patten 1998). Yet despite their importance to humans and wildlife, a significant portion of Montana's wetlands have been lost or degraded (Dahl 1990, Scott et al. 2003). Furthermore, assessment of wetland extent and condition has been impeded by the lack of wetland maps. Although the photo interpretation has been completed for the National Wetlands Inventory (NWI) in Montana, digital maps have not been produced for much of the state. Because the NWI is now over 20 years old, Montana's Wetland Council has encouraged new NWI mapping rather than simply digitizing the old maps. This mapping has recently been undertaken by the Wetland and Riparian Mapping Center of the Montana Natural Heritage Program.

The present study was a pilot project to investigate ways to enhance the new mapping through additional classifications and modifiers. Specifically, our goals were to:

- Evaluate GIS-based approaches to Hydrogeomorphic (HGM) classification and profiling;

- Conduct an HGM functional assessment of the Gallatin Valley study area based on these classifications and profiles;

- Establish a crosswalk between NWI classifications, HGM classifications, and vegetation associations;

- Determine whether these additional classifications and associations could be efficiently linked with National Wetland Inventory in future mapping.

\section{Classification and Assessment}

The NWI classification system (Cowardin et al. 1979) is hierarchical, with an increasing level of detail. There are five broad Systems, three of which exist in the interior United States: Palustrine, Lacustrine, and Riverine. Systems are further divided into Subsystems; for example, Lacustrine Systems may be Limnetic or Littoral; Riverine Systems may be Upper Perennial, Lower Perennial, Intermittent, etc. No Subsystems occur in the Palustrine System. Systems and Subsystems contain Classes describing the substrate, or, in the case of Palustrine wetlands, the vegetation lifeform (e.g. emergent, scrub-shrub, forested, etc), and hydrologic modifiers describe the water regime.

Most Montana wetlands are Palustrine. This System generally includes any wetlands not within a stream or river channel (Riverine System) or within bodies of water which are either larger than 20 acres OR deeper than 6.6 feet (Lacustrine System). Palustrine systems can be found in a broad range of landscape positions and across a variety of ecological classifications, encompassing such diverse wetland types as mountain fens and floodplain oxbows. Consequently, it is difficult to determine the specific habitat or ecological functions and benefits of a given Palustrine wetland simply from its Class.

The Hydrogeomorphic (HGM) approach (Brinson et al. 1993) is also a nationwide wetland classification system, but emphasizes wetland function, recognizing some wetlands perform certain hydrologic, habitat, or biochemical functions more effectively than others. Our objective was to determine if we could develop a GIS-based method to link HGM types to NWI types in the study area, and to assess whether this could be done in other watersheds or on a larger scale. We hoped a geospatial HGM classification key would provide a cost-effective, streamlined methodology for associating wetland functions with NWI types, so evaluations of function and condition could be accomplished with a GIS. We recognize, of course, GIS-based assessments are not a substitute for full HGM evaluations, which are based on regional reference conditions and require substantial field investigations. However, recent studies in Maryland (Tiner et al. 2000) 
and Colorado (Johnson 2005) have illustrated the value of this methodology for initial, coarse-scale characterization and assessment.

We were especially interested in the approach described by Johnson (2005) as Hydrogeomorphic Wetland Profiling (HGM WP). In non-impacted settings, wetland abundance and diversity of wetland types are linked to such landscape-level factors as geomorphology, basin hydrology, and regional or local climate (Johnson 2005). Consequently, similar landscapes can be expected to have similar wetland "profiles." When landscapes are altered by human activity, it follows that these profiles, too, will change. The goal of HGM WP is to determine if differences in wetland abundance and diversity across a region are attributable to differences in the physical setting or rather to disproportionate impacts caused by human activities. Johnson (2005) was able to use HGM WP with some success in Summit County, Colorado. Although we recognized the extreme physical gradients and concentrated human impacts characteristic of Summit County differed significantly from gradients and impacts in our relatively homogeneous study area, we wanted to test out the approach to determine its utility for future use.

\section{Crosswalk between NWI Classifications, HGM Classifications, and Vegetation Associations}

While NWI and HGM classifications are information rich, we believed there could be significant added value in our ongoing mapping efforts if even more classification systems could be associated with the mapped NWI types. The National Vegetation Classification System (NVCS, Grossman et al. 1998) has described specific vegetation associations occurring in Montana and nationwide. Hansen et al. (1995) also developed descriptions of riparian types in Montana, which are widely used. Both NVCS and Hansen et al. (1995) descriptions include detailed accounts of associations and their components, and provide interpretative information on ecological and management characteristics. If NWI and HGM classifications could be linked with NVCS and/or Hansen et al. (1995) associations, either across the board or in specific environmental contexts, wetland maps would be greatly enhanced.

By attempting a crosswalk in this relatively homeogenous study area, we hoped to gauge whether this would be an efficient way to enhance NWI maps.

\section{The Study Area}

The present work is an extension of ecological surveys and evaluations of wetland and riparian habitats, carried out by a group of university, state, local and MTNHP researchers in the 410,000acre lower basin of the Gallatin River watershed, commonly referred to as the Gallatin Valley (Figure 1). It is essentially the same study area as was used by the Gallatin Local Water Quality District (2004) in their assessment of wetland and riparian resources in the valley, minus the Bozeman Creek watershed. The study area includes all or part of nine 5th-code USGS Hydrologic Units (HUCs): Bridger Creek, Camp Creek, Dry Creek, Gallatin River-Gallatin Gateway, Hyalite Creek, Lower East Gallatin, Lower Gallatin, Smith Creek, and Upper East Gallatin. The study area boundary was initially drawn by the Gallatin Local Water Quality District to encompass the large concentration of wetlands in the valley. We continued to use it for consistency, and because this is the only part of the lower Gallatin watershed for which NWI digital maps are available. However, NWI mapping is not complete even within these boundaries. We note too the study area does not include most of the uplands surrounding the valley, where additional (unmapped) wetlands may exist.

The study area is within the Gallatin River subbasin, itself part of the Upper Missouri River Basin. The subbasin covers almost 1.2 million acres, extending from the Yellowstone Plateau to the Gallatin Valley (Figure 1). Upper portions of the subbasin receive over 40 inches of rain per year. The Gallatin Valley, however, is sub-arid, with a typical precipitation average of 12 inches per year (Western Regional Climate Center 2006). 


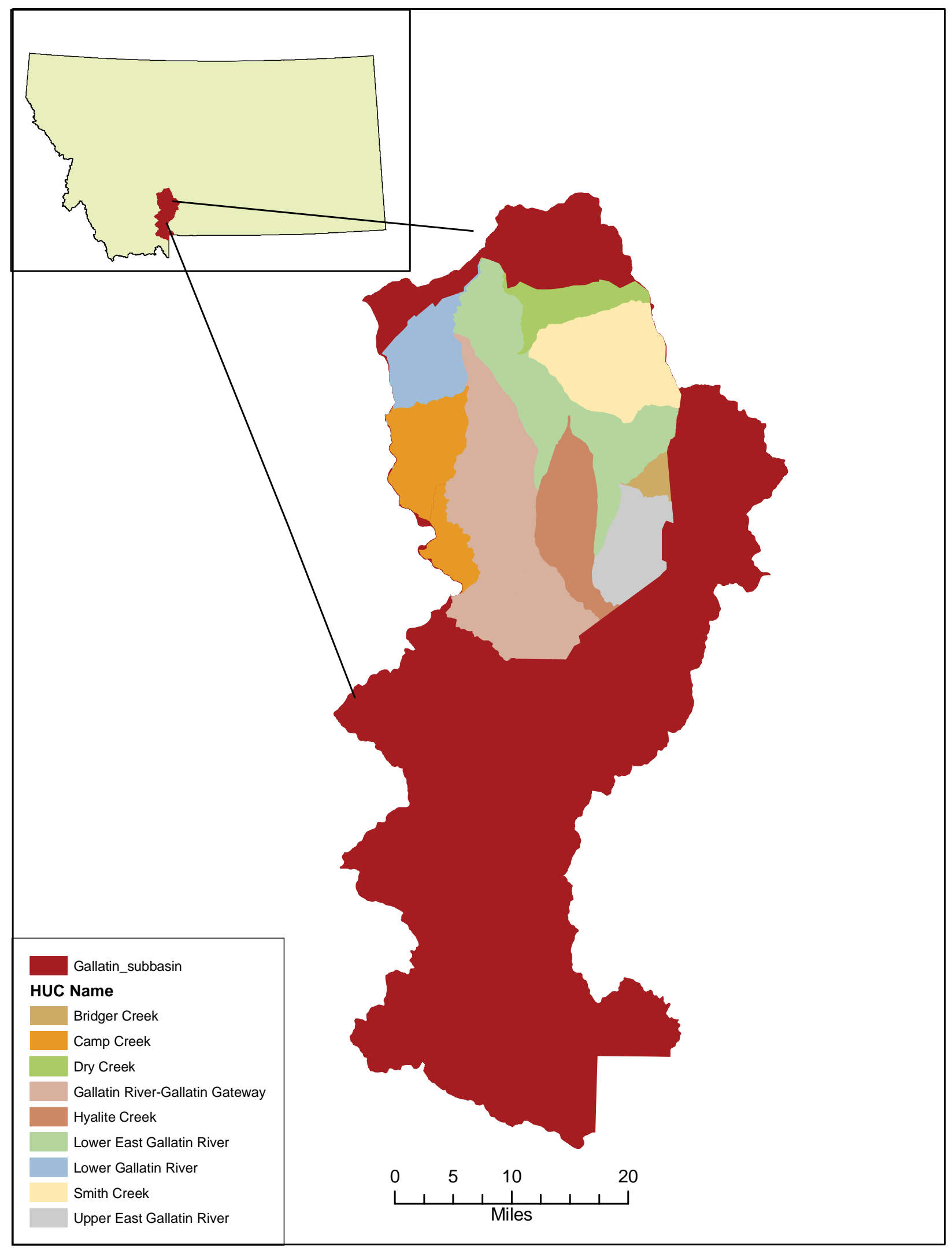

Figure 1. Location of study area. 
Two main river systems dominate Gallatin Valley hydrogeomorphology. The West Gallatin River (typically referred to simply as the Gallatin River) flows for over 100 miles from its origin in Yellowstone National Park to its confluence with the Madison and Jefferson Rivers at the Missouri Headwaters. The East Gallatin River originates in the Bridger Mountains east of the study area, and joins the main Gallatin River 41 miles later near Manhattan. Several perennial streams flow from the mountains south and east of the Valley to join the East Gallatin and Gallatin Rivers. These rivers and perennial streams have left extensive alluvial deposits in the Valley, and as a result, the Valley overlies a thick aquifer system, as much as 600 feet deep at Belgrade (Bridger Outdoor Science School, no date). In many parts of the Valley, depth to groundwater is less than 3 feet.

Abundant water and fertile soils support agriculture throughout the Valley, but especially in its northern and eastern range, where wheat, barley, alfalfa and hay fields are common. The high groundwater table also supports an extensive complex of wetland vegetation in swales and ditches, along rivers and streams, and in low-lying depressions (Figure 2). Wetland vegetation ranges from the cottonwoods, dogwood, chokecherry, willows and alder in seasonally flooded riparian forests to the reeds, sedges, and rushes found in swales. In the study area as a whole, the National Wetlands Inventory has identified nearly 5,830 acres of wetlands. ${ }^{1}$ The northern and northeastern portions of the study area (Lower East Gallatin and Lower Gallatin watersheds), which are the general discharge areas for the aquifer, have the highest concentration of non-riparian wetlands. The watersheds associated with the Gallatin and East Gallatin River (Gallatin River-Gallatin Gateway, Hyalite Creek and Lower East Gallatin) have extensive floodplain and riparian wetland systems. The southeast, northeast, and western portions of the study area (Bridger Creek, Camp Creek, Upper East Gallatin) have relatively few wetland features.

The Gallatin Valley is one of Montana's fastestgrowing areas, having gained 34\% in population between 1990 and 2000 (Census 2000). Gallatin County estimates an addition $21 \%$ population increase by 2010. Most of the Valley is privately owned, while uplands have a high concentration of public ownership (Figure 3). With farmland rapidly being converted to residential land, and increased pressure on water resources from both extraction and discharge, wetland and riparian resources are at considerable risk.

\footnotetext{
${ }^{1}$ The National Wetlands Inventory did not map all riparian forests as wetlands, excluding those that are not at least seasonally flooded. As a result, this acreage does not adequately reflect the extensive riparian areas along the Gallatin and East Gallatin Rivers and the larger streams.
} 


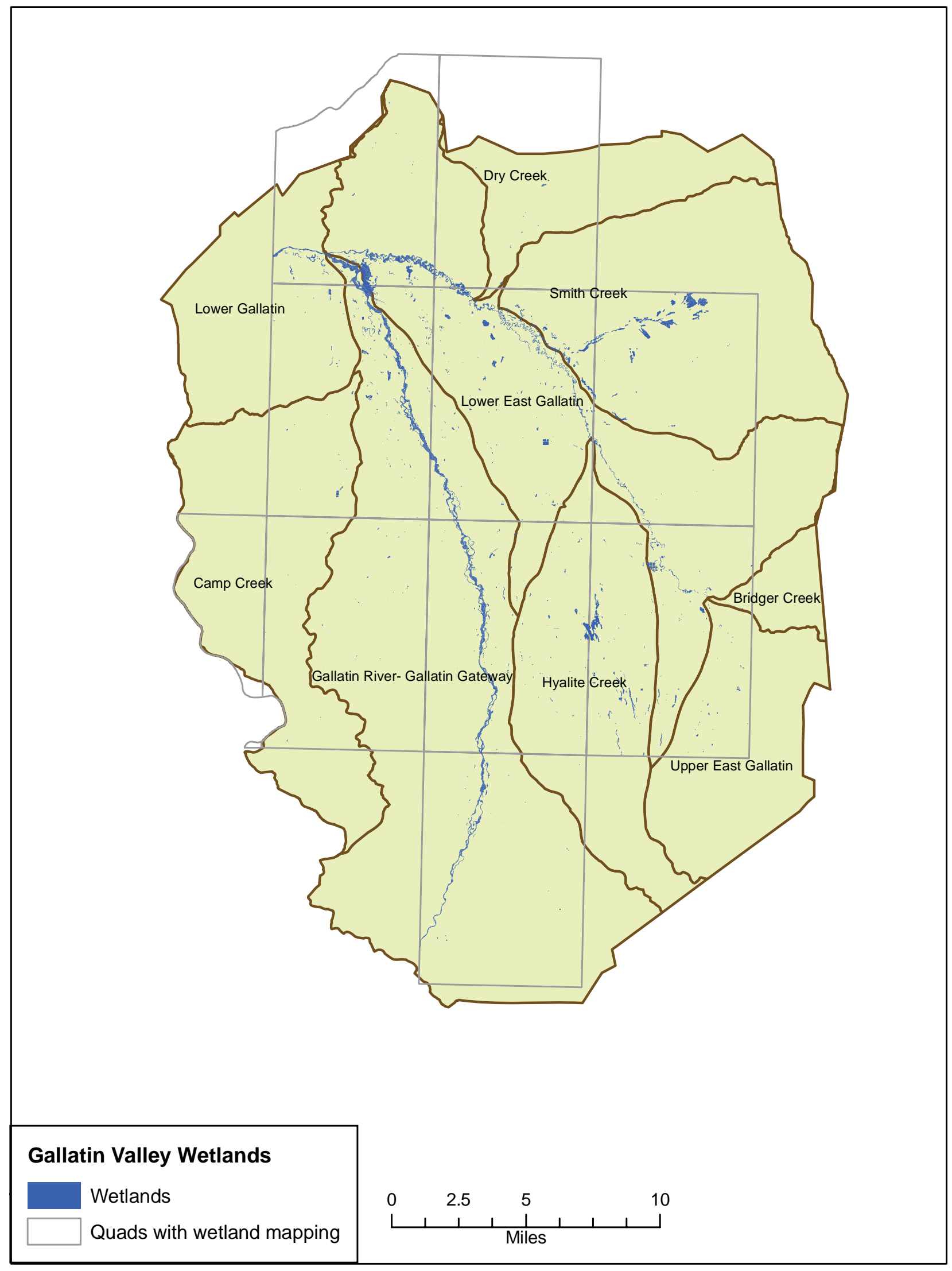

Figure 2. Mapped wetlands, Gallatin Valley. 


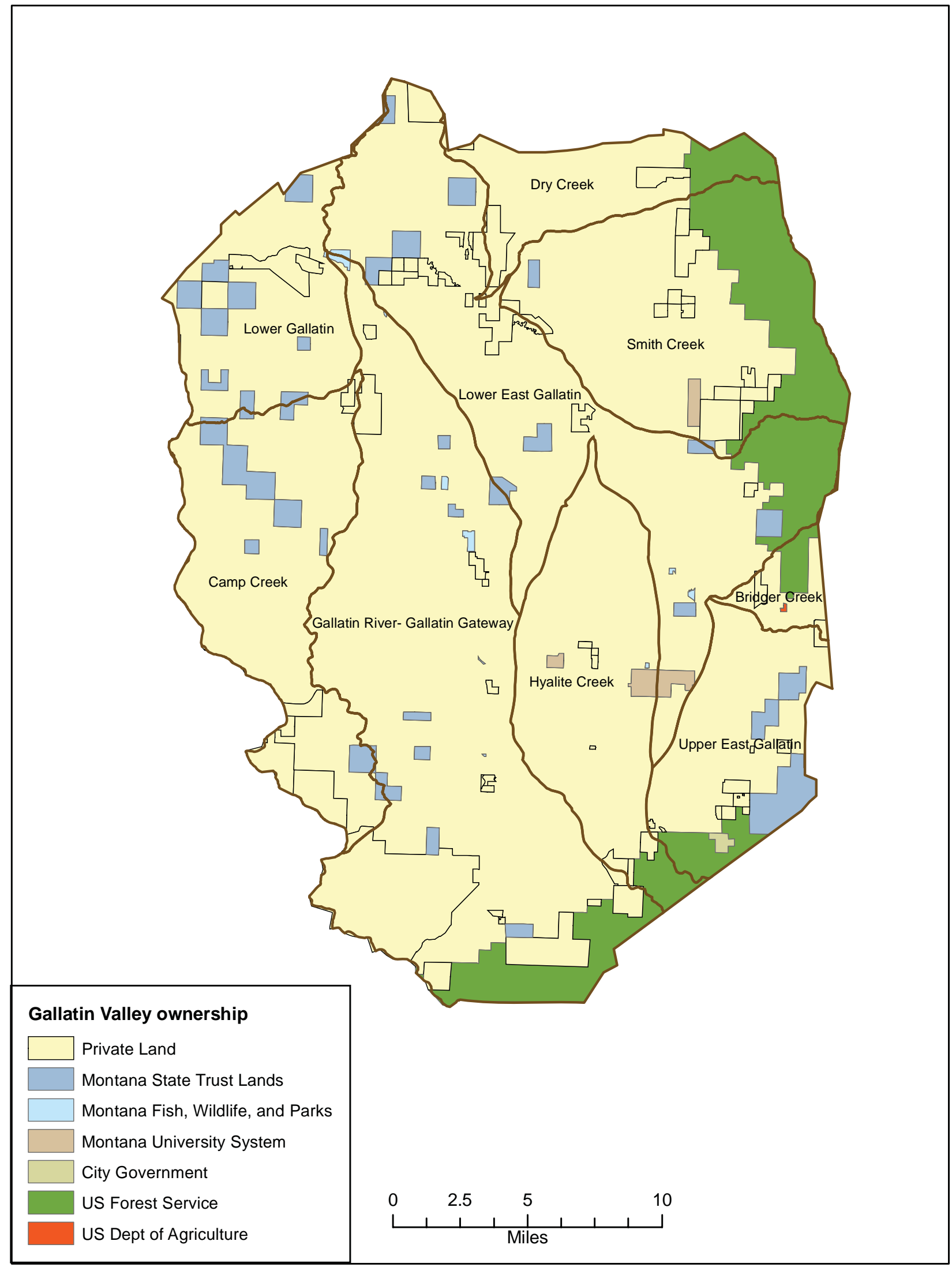

Figure 3. Public and private ownership, Gallatin Valley. 


\section{Methods}

\section{HGM-based Classification and Assessment}

\section{Classification}

We used ArcGIS 9.1 (ESRI 2005) and several data sources (Table 1) to create a Geographic Information System (GIS) with layers representing elevation, soils, streams, wetlands, land cover, parcel ownership, conservation holdings, roads, and potential water impacts in the study area. We underlaid true color 1-meter National Agricultural Imagery Program (NAIP) aerial photos from 2005 on the GIS to allow verification of features, since land cover and wetland layers were more than ten years old. Using dichotomous keys developed by Tiner (2003a) and Johnson (2005), we made several passes over the data to assign HGM classes to wetlands identified by the NWI, basing assignments on landscape position, relationship to stream and river features, and soils, and visually inspecting the outcome on the NAIP imagery. The

Table 1. GIS data sources.

\begin{tabular}{|c|c|c|c|}
\hline Layer Name & Data Source & Description & $\begin{array}{l}\text { Usable } \\
\text { Mapping scale }\end{array}$ \\
\hline National Wetlands Inventory & $\begin{array}{l}\text { U.S. Fish and Wildlife Service, } \\
\text { National Wetlands Inventory }\end{array}$ & $\begin{array}{l}\text { Digital data based on 1:24000 aerial photos } \\
\text { from 1980's }\end{array}$ & $1: 24,000$ \\
\hline Montana 5th -code watersheds & $\begin{array}{l}\text { Natural Resource Conservation } \\
\text { Service }\end{array}$ & U.S. Geological Survey Basemaps, 1996 & $1: 100,000$ \\
\hline National Land Cover Dataset & $\begin{array}{l}\text { U.S. Geological Survey, Biological } \\
\text { Resource Division }\end{array}$ & 30m pixel Landsat Imagery, 1992 & $1: 60,000$ \\
\hline Soil Surveys & $\begin{array}{l}\text { Natural Resource Conservation } \\
\text { Service }\end{array}$ & SSURGO and MTNASIS & $1: 24,000$ \\
\hline National Hydrography Dataset & U.S. Geological Survey and EPA & Provisional high-resolution flowline, 2006 & $1: 24,000$ \\
\hline $\begin{array}{l}\text { Montana Stewardship } \\
\text { Database }\end{array}$ & Montana Natural Heritage Program & $\begin{array}{l}\text { Updated easement and administration, } \\
2006\end{array}$ & $1: 24,000$ \\
\hline Cadastral Database & $\begin{array}{l}\text { Montana Department of } \\
\text { Administration }\end{array}$ & Cadastral records, 2006 & variable \\
\hline Montana Roads & U.S. Census Bureau 2000 & U.S. Geological Survey 1:100,000 maps & $1: 100,000$ \\
\hline Census Groups 2000 & U.S. Census Bureau 2000 & Ten-year census data with census tracts & variable \\
\hline $\begin{array}{l}\text { Water Rights Points of } \\
\text { Diversion }\end{array}$ & $\begin{array}{l}\text { Montana Department of Natural } \\
\text { Resources and Conservation, Water } \\
\text { Resource Division } 2006\end{array}$ & $\begin{array}{l}\text { Estimated from legal land descriptions or } \\
\text { geographical coordinates }\end{array}$ & variable \\
\hline Groundwater Wells & $\begin{array}{l}\text { Montana Groundwater Information } \\
\text { Center }\end{array}$ & $\begin{array}{l}\text { Estimated from well drilling logs, water } \\
\text { rights filings, field surveys }\end{array}$ & $1: 24,000$ \\
\hline Septic Density & U.S. Census Bureau 2000 & $\begin{array}{l}\text { U.S. Geological Survey Maps and survey } \\
\text { data }\end{array}$ & $1: 100,000$ \\
\hline Corps 404 permits & $\begin{array}{l}\text { Natural Resource Information } \\
\text { Service }\end{array}$ & Reports from Army Corps of Engineers & $1: 24,000$ \\
\hline Wastewater Permits & Montana DEQ, 2000 & Extracted from DEQ records & $1: 24,000$ \\
\hline
\end{tabular}


keys were refined until the GIS-based classification and visual inspection produced agreement in 90 of 100 randomly selected wetlands (Appendix A). Approximately $15 \%$ of the wetlands in the study area could not be classified using keys; these were classified manually. HGM attributes were then coded onto the NWI attribute tables, and statistical summaries were carried out to evaluate the distribution of HGM types across the study area watersheds.

HGM terminology followed categories described by Tiner (2003a) in his work with NWI enhancements in Maryland. This terminology differs from other HGM classifications in its use of such terms as "Terrene" and "Lotic" instead of "Depressional" or "Riverine," and by its extension of the term "Flat" to mean any wetland not having a distinct basin form and is located on relatively level ground. The decision to use Tiner's terminology was based on a desire to maintain consistency of NWI products and enhancements. A description of each of the terms can be found in Table 2.

Table 2. HGM terms and descriptions used in this study.

\begin{tabular}{|c|c|}
\hline HGM LANDSCAPE POSITION & Definition \\
\hline Lentic & $\begin{array}{l}\text { Associated with a lake, reservoir, or other large, standing water body. } \\
\text { There were no lentic wetlands in the study area. }\end{array}$ \\
\hline Lotic River & $\begin{array}{l}\text { Associated with a flowing water system depicted as a } 2 \text {-line feature on } \\
\text { a 1:24,000 USGS topo map. }\end{array}$ \\
\hline Lotic Stream & $\begin{array}{l}\text { Associated with a flowing water system depicted as a single-line feature } \\
\text { on a 1:24,000 USGS topo map. }\end{array}$ \\
\hline Terrene & $\begin{array}{l}\text { Surrounded or almost surrounded by uplands. These wetlands may } \\
\text { have inlet or outlet channels, but do not have a channel entering and } \\
\text { exiting. Includes human-made ponds. }\end{array}$ \\
\hline HGM GRADIENT (with Lotic landscape position) & Definition \\
\hline Lower Gradient & $\begin{array}{l}\text { The slower-flowing area of a river or stream characterized by meanders } \\
\text { and floodplain development. Corresponds to NWI Lower Perennial. }\end{array}$ \\
\hline Middle Gradient & $\begin{array}{l}\text { Faster-flowing area of a river or stream with limited floodplain } \\
\text { development. Corresponds to NWI Upper Perennial. }\end{array}$ \\
\hline HGM LANDFORM & Definition \\
\hline Basin & $\begin{array}{l}\text { A depressional landform occurring in upland soils or on floodplains (e.g. } \\
\text { oxbow). NWI Aquatic bed sites are always classified as Basin. Can be } \\
\text { part of Terrene or Lotic landscape position. }\end{array}$ \\
\hline Flat & $\begin{array}{l}\text { A level landform, usually but not always on a floodplain or interfluve. } \\
\text { Typically only identified from visual inspection. }\end{array}$ \\
\hline Floodplain & $\begin{array}{l}\text { Broad, flat landform shaped by riverine or other fluvial processes. In this } \\
\text { case the area defined by the presence of soils listed as floodplain soils } \\
\text { in the NRCS SSURGO database. Can be further described as Basin, } \\
\text { Flat, or Oxbow through combination of GIS and visual inspection. }\end{array}$ \\
\hline Fringe & $\begin{array}{l}\text { Wetland on the margin of a stream, river, pond, or lake. Includes non- } \\
\text { vegetated or sparsely vegetated point bars along a river's edge. }\end{array}$ \\
\hline Island & $\begin{array}{l}\text { A landform that is completely surrounded by a stream, river, pond, or } \\
\text { lake. }\end{array}$ \\
\hline
\end{tabular}


Table 2. Continued.

\begin{tabular}{|l|l|}
\hline HGM WATER PATH & Definition \\
\hline Inflow & $\begin{array}{l}\text { A wetland receiving ground or surface water but with no significant } \\
\text { discharge. Typically only identified through visual inspection. }\end{array}$ \\
Isolated & $\begin{array}{l}\text { A terrene wetland with no apparent surface water inflow or outflow. } \\
\text { A wetland with surface or groundwater flowing through it to a } \\
\text { water body or another wetland. Throughflow may be ephemeral or } \\
\text { intermittent. }\end{array}$ \\
\hline
\end{tabular}

\section{Assessment}

Johnson (2005) used geology, hydrology, climate and elevation to assign Summit County 6th code HUCs into three relatively homogeneous process domains (sensu Montgomery 1999), and then assigned them into impact categories ("reference" and "impacted") based on land cover and road density. He was then able to determine whether characteristic wetland profiles differed between the three process domains (yes) and between impacted and reference examples of individual process domains (yes). Our initial intent was to follow his methodology in our study area, but when we examined our GIS, we determined the mapped wetlands were almost entirely confined to a single geologic layer (alluvium), and a narrow elevation band (1250m to $1575 \mathrm{~m})$ within a $12-14$ inch precipitation zone. Principal components analysis (MVSP 2003) of the GIS led to the determination that 5th code HUCs would be the best units of analysis, since they had sufficient homogeneity on the one hand and enough impact variability on the other to make comparisons. Furthermore, 5th code HUC boundaries are well-defined, and are used in NRIS's GIS Data Bundler and Digital Atlas applications, allowing anyone who wishes to examine further attributes of the landscape units in this study to do so.

We also used principal components analysis to separate the 5th code HUCs into impact categories. We added several impacts to the ones used by Johnson (2005), evaluating road density, land cover, population density, septic density, average parcel size, percentage of private land ownership, percentage of public ownership and easements. Because field surveys revealed extensive weed infestation in the study area, we also included percentage of public land survey sections with one or more noxious weeds as an impact. Based on these impact factors, 5th code HUCs were ranked from "Less Impacted" to "More Impacted." (We did not feel the term "reference" was appropriate in the study area, even in a relative context.) We examined a suite of additional factors to determine whether they would affect the analysis (water diversions, Section 404 Clean Water Act permits, wastewater discharge permits and number of groundwater wells relative to wetland acreage), but did not find these changed the outcome of the analysis.

Once 5th code HUCs were determined as units of analysis and impact categories assigned, we tallied areal coverage of each HGM class within each HUC and summed HGM classes using the geoprocessing functions of ArcGIS 9.1. These were then exported into Microsoft Excel, and pivot table functions were used to generate descriptive statistics of HGM classes. Functions were identified from a review of HGM literature (Brinson 1993, Jankovsky-Jones et al. 1999a and 1999b, Hauer et al. 2002a and 2002b, Sheldon et al. 2003, Tiner et al. 2000, Tiner 2003a and 2003b) and professional opinion.

The study assessed eight wetland functions: 1) surface water detention and streamflow maintenance; 2) nutrient cycling; 3) sediment trapping; 4) plant community maintenance, 5) shoreline stabilization; 6) aquatic habitat; 7) terrestrial habitat; and 8) conservation of wetland biodiversity. We assigned functions to wetlands as a class, rather than to individual wetlands, so size was not considered as a factor. We then ranked each wetland class as having "high", "moderate" 
or "low" importance vis-à-vis that function, based on literature reviews, field surveys in the Gallatin Valley, and professional opinion.

1) Surface water detention and streamflow maintenance. Floodplain wetlands, especially along lower gradient streams and rivers, are typically inundated during flood events, and to a lesser degree, during overbank flows. These wetlands reduce flood peaks by capturing and storing water; stored water is released later, helping to maintain baseline flows. We ranked Lotic River and Lotic Stream Lower Gradient Floodplain wetlands "high" on this category. Island wetlands, fringe wetlands, and Middle Gradient Lotic wetlands were given a "moderate" ranking on this category, as they typically do not store as much floodwater (Tiner 2003a). Terrene Interfluve Basin wetlands, while not on floodplain soils, may receive and store considerable amounts of snow and rainfall, and are often groundwater recharge and discharge sites. Because of their landscape position (the interfluve area), they contribute to both detention and streamflow maintenance, so these were also given a "moderate" ranking. Terrene wetlands not in the interfluve area and Terrene Interfluve Flat wetlands were ranked as "low.

2) Nutrient cycling. Forested riparian wetlands, thickly vegetated upland wetlands, and ponded wetlands with aquatic bottoms all take up and recycle nutrients (e.g. nitrogen and phosphorus). Streamside wetlands, through their sediment trapping functions, further reduce phosphorus input into flowing waters. We ranked all Terrene Basin wetlands as high on this function, and all Floodplain wetlands as moderate, although we note that if we were assessing individual wetlands these ratings could change depending on vegetation structure (i.e. large Basin wetlands with substantial open water could rank "moderate" and some heavily vegetated floodplain wetlands could rank "high.”). Fringe wetlands and flat wetlands were ranked "low," because vegetation is often sparse in the former, and flat wetlands do not generally contain as much organic matter as basin wetlands.
3) Sediment trapping. All wetlands perform some sediment trapping functions, but these functions are especially significant near watercourses in agricultural areas. Therefore, we gave all Floodplain and Interfluve Basin wetlands a ranking of "high" on this category, while upland Terrene Basins were rated as "moderate" and all Flat wetlands were rated as "low."

4) Plant community maintenance. Wetlands with fluctuating water table depths, layered soils, and organic matter can support the most diverse plant communities, while wetlands with considerable open water or wetlands subject to ice scour and frequent bankful flows cannot. We gave floodplain wetlands a "high" score in this category, because they typically have the characteristics associated with high plant diversity. Beaver ponds were ranked low because of the open water associated with them (the edges of beaver ponds in the Gallatin are characterized simply as Floodplain wetlands, and therefore rank as "high"), as were Flat wetlands, because they trap less organic matter and have less of the horizontal complexity that leads to plant diversity. All other wetlands received a score of "moderate" on this function.

5) Shoreline stabilization. This is an important function for wetlands in coastal, estuarine, and lacustrine settings, none of which are found in the Gallatin. In our study area, the only shoreline exists along rivers and streams. Floodplain throughflow wetlands were all ranked as high on this function. Fringe wetlands often contain deep-rooted vegetation providing critical bank anchoring, but because many of them are associated with unstable substrates, and have little deep rooted vegetation in the Gallatin, we gave the class as a whole a ranking of "moderate." Beaver ponds, basins, and Lotic Island wetlands were given a rating of "low."

6) Aquatic habitat. Fringe, and island wetlands offer cover, nutrient inputs, temperature moderation, and juvenile and rearing habitat for fish, especially along lower gradient rivers and streams, so these were all ranked as "high." Floodplain wetlands filter sediments that could clog spawning gravels, contribute woody debris 
to streams, and shelter reptiles and amphibians, so these were ranked as "moderate," unless they were beaver ponds, in which case they were "high." Basins are critical to reptiles and amphibians, so these too were given a rating of "high." Flat wetlands were ranked as "low" because they typically lack open water and have less structural diversity.

7) Terrestrial habitat. Woody wetlands offer food, shelter, access to water, and breeding and reproduction sites for a wide range of mammals and birds, so all Floodplain wetlands received a "high" ranking in this category. Interfluve basins, because of their proximity to woodlands and their own structural complexity, also have considerable habitat value for birds and small mammals, so they too were ranked as high. Non-interfluve basins and Interfluve Flat wetlands were given a score of "moderate," while Lotic Fringe and island wetlands, which provide more limited terrestrial habitat, were ranked as "low."

8) Conservation of wetland biodiversity. These rankings were assigned ex post facto based on the representation of wetland classes in the study area. The least common wetlands were given a ranking of "high," while the most common and wellrepresented wetlands were scored as "low" and "moderate," respectively.

\section{National Wetlands Inventory Enhancement}

Sites for field sampling were selected by using existing NWI mapping to identify locations we could access and represented the spectrum of NWI types. We coordinated with the Gallatin Valley Water District to gain private land access. Sites were characterized for vegetation and the correct NWI type was recorded if the mapped type was incorrect. Vegetation communities were coded to the closest NVCS or Hansen et al. (1995) type and a crosswalk table was constructed.

We adapted the HGM modifier key developed by Tiner (2003a) to test the application of HGM modifiers to NWI delineations in the field. Major NWI types were assessed for their ecological functions through a review of the HGM literature cited above and professional opinion, and were added to the crosswalk.

To refine the crosswalk for future use in mapping, we wanted to determine if any or all of the Palustrine and Riverine wetland classes would predictably align with a specific HGM class. If this were so, then future mapping efforts could use a simple "if-then" logic approach to assign HGM categories to given NWI attributes. Because we had observed a one-to-many relationship in our visual inspection of the data, we began by testing the hypothesis NWI Riverine types would always be HGM Lotic types and NWI Palustrine types would always be HGM Terrene types. As we suspected, NWI Riverine types had a oneto-one relationship with HGM Lotic types, both as a group and one a class-by-class basis, but HGM Lotic types had a one-to-many relationship with NWI Riverine types. All Palustrine types had complicated one-to-many relationships with HGM classes. We then constructed a pairwise comparison/correspondence table, using numerical scores of 1 to 10 to represent the percentage of observed incidences of an exact pairwise match (see Table 5 under Results, below) However, we urge the reader to refer to the dichotomous key rather than to the correspondence table to extend this methodology beyond the Gallatin. This caveat is discussed more fully under the Results section, below. 


\section{Results}

\section{HGM Classification of Wetlands}

Tables 3 and 4 show the breakdown of HGM types across the study area, as determined by our classification keys and accompanying visual inspections. We used a total of 32 HGM classifications, 17 for unaltered wetlands and 15 for altered wetlands. Nearly $85 \%$ of the wetland acreage in the study area is classified as Lotic. In the NWI classification scheme, the Riverine System includes only those wetlands within the active channel of a flowing water feature depicted as a 2-line channel (i.e. a channel wide enough to be represented as an area, rather than a single line) on a 1:24,000 USGS topo map. Riverine wetlands most typically include fringe wetlands along the river's edge, mid-channel islands and point bars submerged at bankful flow, and side channels completely flooded by the river at least part of the year. Stable point bars and floodplains above the active channel are classified as Palustrine, even if their main source of water is over-bankful flows. By contrast, Lotic wetlands in the HGM system include all those wetlands found within the approximate 100-year floodplain, as that is determined from floodplain maps or soils maps indicating floodplain soils. Lotic wetlands would therefore include wetlands along the margin of single-line channels (i.e. streams), saturated backwaters, old meanders, oxbows, and the like. In this way, the Terrene-Lotic HGM classification dichotomy conveys more information about the origin and hydrology of wetlands in a given area than does the Riverine-Palustrine dichotomy. It is not surprising, therefore, that Lotic wetland acreage is concentrated in the Gallatin RiverGallatin Gateway (47\%) and Lower East Gallatin (25\%) watersheds, because these watersheds contain the main Gallatin River and East Gallatin River channels. Smaller proportions are found in the Smith Creek (10\%) and Hyalite Creek (9\%) watersheds. Terrene wetland acreage is most plentiful in the Lower East Gallatin (41\%) and Smith Creek (27\%) watersheds.

Wetland alterations (draining, ditching, impounding, excavating) were determined solely by reference to NWI polygon attributes, except when the polygon in question had to be visually inspected for its primary classification or for accuracy. For example, a Palustrine, Aqautic Bed, Semipermanently Flooded, Diked/Impounded (PABFh) polygon entirely surrounded by upland soils would be classified by the GIS as a Terrene, Basin, Diked/Impounded HGM type. In the study area as a whole, less than $8 \%$ of the wetland acreage fell into the altered category, although when wetland numbers were considered, almost $17 \%$ of wetlands were altered in some way. This suggests two possibilities: first, smaller wetlands are more susceptible to manipulation or alteration and second, activities such as draining, ditching, impounding or excavation typically result in the creation of small wetlands. Alterations also tend to be clustered on upland soils. Although $85 \%$ of all the wetland acreage in the study area is Lotic, as noted above, $72 \%$ of the altered wetland acreage is Terrene.

\section{HGM Assessment of Wetlands}

Figures 4, 5 and 6 show the watershed boundaries for the 5th code HUCs over maps of the geology, elevation, and hydrologic features of the study area.

The Gallatin River-Gallatin Gateway watershed and the Lower East Gallatin watershed were the most similar of the landscape units (i.e. 5th code HUCs) . Each has a major (4th or 5th order) river flowing through a broad, alluvial valley. Both have uplands of sedimentary rock and (at higher elevations) gneiss and schist, and both are in the 12-14 inch precipitation zone. The main difference between them is in elevation; the East Gallatin River originates in a lower elevation band than the Gallatin River. This is reflected in the wetland profiles; although they have similar proportions of Lotic and Terrene wetlands, including interfluve wetlands, the Gallatin River-Gallatin Gateway watershed has over 500 acres of Lotic Stream and Lotic River Middle Gradient Floodplain wetlands, while the Lower East Gallatin has none.

The Hyalite Creek watershed was similar to these two in terms of geology and precipitation, but is higher in elevation, with only its northern end in 
Table 3. Unaltered wetland acreage in the study area, by HGM class.

\begin{tabular}{|c|c|c|c|c|c|c|c|c|c|c|}
\hline HGM CLASS & Bridger Ck & Camp Ck & Dry Ck & Gallatin River & Hyalite Ck L & \begin{tabular}{|l|l} 
Lower E. Gallatin \\
\end{tabular} & Lower Gallatin & Smith Ck & Upper E. Gallatin & Total \\
\hline Appears to have been drained* ${ }^{*}$ & & & & 0.69 & 0.21 & 6.05 & & & & 6.95 \\
\hline Lotic River, Intermittent, Floodplain, Ex & & & & & & & 0.52 & & & 0.52 \\
\hline Lotic River, Lower Gradient, Floodplain, D/l & & & & 1.71 & & & & & & 1.71 \\
\hline Lotic River, Lower Gradient, Floodplain, Ex & & & & 0.69 & & & & & & 0.69 \\
\hline Lotic River, Middle Gradient, Floodplain, D/l & & & & 0.51 & & & & & & 0.51 \\
\hline Lotic Stream, Lower Gradient, Floodplain, D/D & & & & & 19.19 & 18.00 & & 23.12 & & 60.31 \\
\hline Lotic Stream, Lower Gradient, Floodplain, D/I & & 0.84 & 1.04 & 14.46 & 8.19 & 4.19 & & 2.94 & 1.01 & 32.67 \\
\hline Lotic Stream, Lower Gradient, Floodplain, Ex & & 0.59 & & 17.41 & 3.14 & 3.27 & 2.07 & & & 26.48 \\
\hline Lotic Stream, Middle Gradient, Floodplain, D/I & & & & 0.81 & 0.48 & & & & & 1.30 \\
\hline Terrene, Basin, D/D & & & & & 12.87 & 8.60 & & 28.70 & & 50.17 \\
\hline Terrene, Basin, D/I & 0.72 & 2.68 & 3.46 & 7.10 & 2.36 & 2.28 & 3.39 & 1.29 & 8.16 & 31.43 \\
\hline Terrene, Basin, Ex & & 11.97 & & 16.41 & & 6.08 & 13.35 & 0.73 & 6.26 & 54.80 \\
\hline Terrene, Interfluve, D/D & & & & & 3.28 & & & & & 3.28 \\
\hline Terrene, Interfluve, Basin, D/D & & & & 1.12 & 1.87 & 7.74 & & & & 10.73 \\
\hline Terrene, Interfluve, Basin, D/I & & & & 1.89 & 5.09 & 4.30 & & & & 11.27 \\
\hline Terrene, Interfluve, Basin, Ex & & & & 27.39 & 30.76 & 115.11 & & & & 173.26 \\
\hline Grand Total (Acres) & 0.72 & 16.08 & 4.50 & 90.19 & 87.43 & 175.61 & 19.34 & 56.77 & 15.43 & 466.07 \\
\hline
\end{tabular}

* These were NWI wetland polygons

examined during the classification and testing

process that were not distinguishable as

wetlands on NAIP imagery. 
Table 4. Altered wetland acreage in the study area, by HGM class.

\begin{tabular}{|c|c|c|c|c|c|c|c|c|c|c|}
\hline HGM CLASS & Bridger Ck & Camp Ck & Dry Ck & Gallatin River & Hyalite Ck & Lower E. Gallatin & Lower Gallatin & Smith Ck & Upper E. Gallatin & Total \\
\hline Appears to have been drained* & & & & 0.69 & 0.21 & 6.05 & & & & 6.95 \\
\hline Lotic River, Intermittent, Floodplain, Ex & & & & & & & 0.52 & & & 0.52 \\
\hline Lotic River, Lower Gradient, Floodplain, D/I & & & & 1.71 & & & & & & 1.71 \\
\hline Lotic River, Lower Gradient, Floodplain, Ex & & & & 0.69 & & & & & & 0.69 \\
\hline Lotic River, Middle Gradient, Floodplain, D/l & & & & 0.51 & & & & & & 0.51 \\
\hline Lotic Stream, Lower Gradient, Floodplain, D/D & & & & & 19.19 & 18.00 & & 23.12 & & 60.31 \\
\hline Lotic Stream, Lower Gradient, Floodplain, D/I & & 0.84 & 1.04 & 14.46 & 8.19 & 4.19 & & 2.94 & 1.01 & \begin{tabular}{l|l}
1 & 32.67
\end{tabular} \\
\hline Lotic Stream, Lower Gradient, Floodplain, Ex & & 0.59 & & 17.41 & 3.14 & 3.27 & 2.07 & & & 26.48 \\
\hline Lotic Stream, Middle Gradient, Floodplain, D/I & & & & 0.81 & 0.48 & & & & & 1.30 \\
\hline Terrene, Basin, D/D & & & & & 12.87 & 8.60 & & 28.70 & & 50.17 \\
\hline Terrene, Basin, D/I & 0.72 & 2.68 & 3.46 & 7.10 & 2.36 & 2.28 & 3.39 & 1.29 & 8.16 & 6 6 31.43 \\
\hline Terrene, Basin, Ex & & 11.97 & & 16.41 & & 6.08 & 13.35 & 0.73 & 6.26 & \begin{tabular}{l|l}
6 & 54.80
\end{tabular} \\
\hline Terrene, Interfluve, D/D & & & & & 3.28 & & & & & 3.28 \\
\hline Terrene, Interfluve, Basin, D/D & & & & 1.12 & 1.87 & 7.74 & & & & 10.73 \\
\hline Terrene, Interfluve, Basin, D/I & & & & 1.89 & 5.09 & 4.30 & & & & 11.27 \\
\hline Terrene, Interfluve, Basin, Ex & & & & 27.39 & 30.76 & 115.11 & & & & 173.26 \\
\hline Grand Total (Acres) & 0.72 & 16.08 & 4.50 & 90.19 & 87.43 & 175.61 & 19.34 & 56.77 & 15.43 & 3. 466.07 \\
\hline
\end{tabular}

* These were NWI wetland polygons exam-

ined during the classification and testing pro-

cess that were not distinguishable as wetlands

on NAIP imagery. 


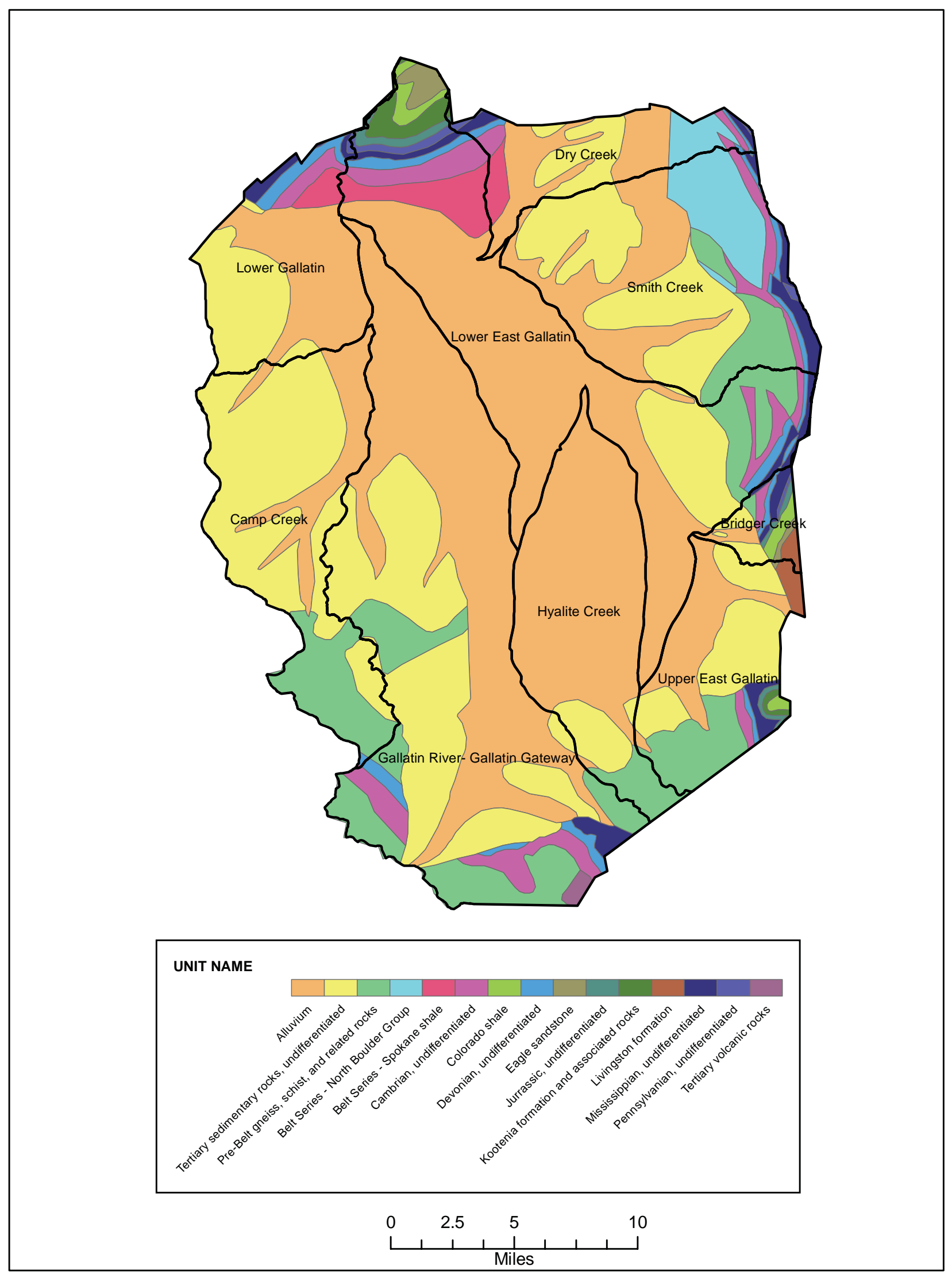

Figure 4. Geology of study area. 


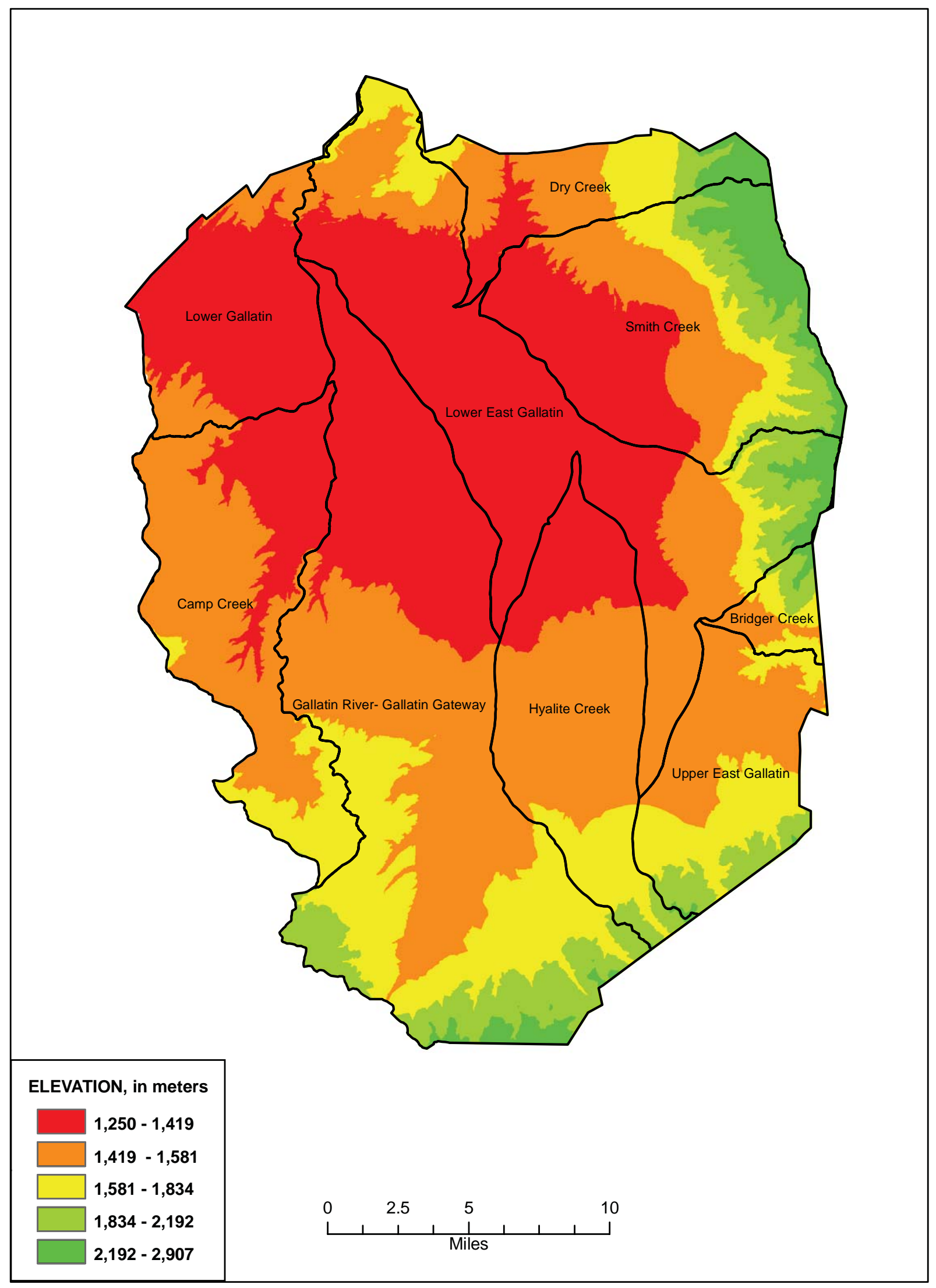

Figure 5. Elevation of study area. 


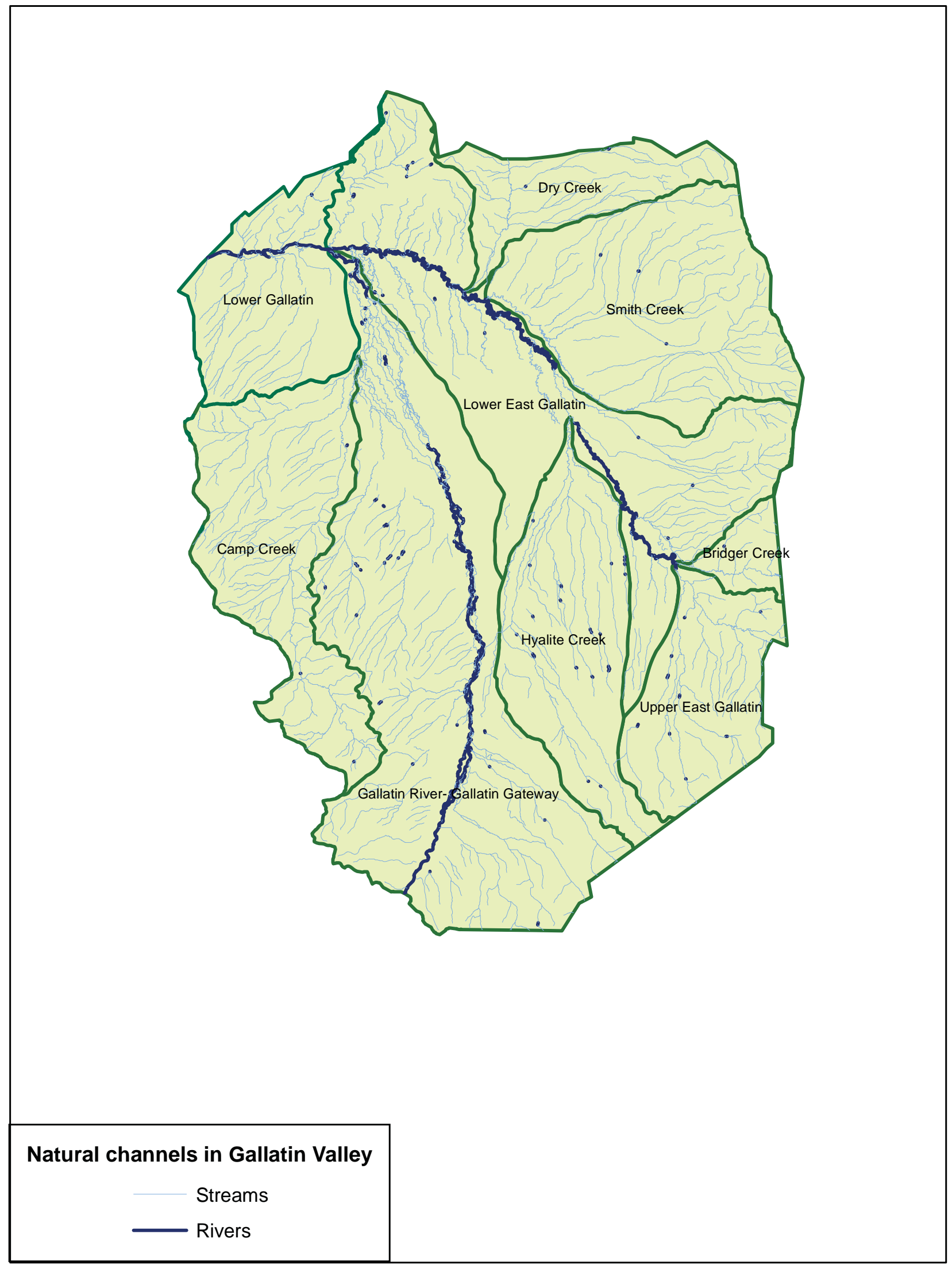

Figure 6. Hydrology of study area. 
the broad, low-lying valley floor, and although its northeastern edge extends into the East Gallatin River floodplain (giving it a complement of Lotic River Floodplain wetlands), it is not bisected by a major river. Like the Lower East Gallatin watershed, the majority of its terrene wetlands are in the interfluve area between the East Gallatin and Gallatin Rivers. No other watershed was suitable for pairing with Hyalite Creek.

The Smith Creek and Dry Creek watersheds in the northeastern part of the study area are similar in most respects, although Smith Creek has a more substantial set of perennial streams, several of them extending onto the East Gallatin floodplain. Many of the wetlands in the Smith Creek watershed were classified as Lotic Stream rather than Lotic River because they were physically closer to stream features than to river features, so the fact that the wetland profiles appear different (Dry Creek has Lotic River Floodplain wetlands while Smith Creek has Lotic Stream Floodplain wetlands) is probably more an artifact of the classification than of any genuine difference.

The portions of the Bridger and Upper East Gallatin watersheds lying within the study area differ from the other seven primarily in their elevational profiles and geology, being generally higher. They also have a higher percentage of gneiss, schists, and sedimentary rocks than alluivium, and share a west-facing aspect. Because only small portions of these watersheds were included in the NWI mapping, it is impossible to say whether they truly have similar wetland profiles, although it appears this is the case, with only scattered Lotic wetlands.

The Lower Gallatin and Camp Creek share similarities in aspect, elevation, precipitation, and geology, but differ insofar as the lower Gallatin includes portions of the Gallatin River. Because of this, their wetland profiles appear to be considerably different, with Camp Creek lacking any significant Lotic River wetlands. However, these watersheds are also not completely mapped, and their profiles may be more similar than they appear.
Table 5 gives the scores on the metrics we used for assessing impacts, as well as additional metrics (e.g. groundwater wells, water diversions) collected but were not useful in the analysis. We were unable to discern any fundamental differences in the wetland profiles of these matched watersheds that could be attributed to impacts. In some cases this was due to the mapping gap. The Bridger Creek/Upper East Gallatin pair had the greatest difference in impact ranks, with Bridger being the least impacted of the watersheds and Upper East Gallatin the most.

However, there are only 2 mapped wetlands in the Bridger Creek watershed and 39 in the Upper East Gallatin. More than half the wetland acreage in the Upper East Gallatin has been altered, which is consistent with its impact ranking, but the same is true of Bridger Creek, where the larger of the two wetlands is altered. Comparisons between these two wetlands watersheds are therefore meaningless. A similar problem exists with the Camp Creek/Lower Gallatin pair, although they are closer on the impact scale (4 and 6, respectively). It appears similar percentages of Terrene wetlands have been directly altered in the two watersheds, but mapping covers only half the watersheds, and in the case of the Lower Gallatin, does not even include all of the Gallatin River.

The Gallatin River-Gallatin Gateway/Lower East Gallatin pair, however, did exhibit differences in line with their impact ranks (5 and 7, respectively), at least in terms of direct alteration. Less than $4 \%$ of the wetland acreage in the Gallatin RiverGallatin Gateway watershed has been directly altered, while alterations have been made to almost $11 \%$ of Lower East Gallatin wetland acreage, accounting for $37.68 \%$ of all altered wetland acres across the entire study area, It may be, therefore, the difference in wetland profiles between these two watersheds (i.e. the absence of Middle Gradient wetlands) has an anthropogenic cause such as residential development along stream corridors. It is also worth noting the Hyalite Creek watershed, which differed from these two watersheds only in having no fourth or fifth order stream, had a higher impact ranking than either of them (8), and the highest percentage of altered 
Table 5. Impacts by 5th-code HUCs in study area..

\begin{tabular}{|c|c|c|c|c|c|c|c|c|c|}
\hline Indicator & Bridger Ck & Camp Ck & Dry Ck & Gallatin R.-GG & Hyalite Ck L & Lower E. Gallatin & Lower Gallatin & Smith Ck L & Upper E. Gallatin \\
\hline 404 permits* & 13 & 0.58 & 0 & 0.03 & 0.08 & 0.06 & 0.03 & 0.01 & 2.84 \\
\hline GW wells* & 69 & 9.79 & 0.47 & 1.2 & 3.63 & 1.49 & 0.89 & 0.54 & 74.8 \\
\hline Water diversions* & 107 & 10.38 & 1.29 & 1.39 & 4.2 & 1.47 & 1.14 & 1.23 & 25.9 \\
\hline Wastewater permits* & 0 & 0 & 0 & 0 & 0 & 0 & 0.01 & 0 & 0.28 \\
\hline Road density** & 13.73 & 10.03 & 9.79 & 17.84 & 29.65 & 27.6 & 17 & 10.24 & 39.16 \\
\hline Population density*** & 0 & 0 & 0 & 0.12 & 0.54 & 0.17 & 0.2 & 0 & 18.4 \\
\hline Human Landcover**** & 13.28 & 79.46 & 59.19 & 59.61 & 83.22 & 53.13 & 73.37 & 51.4 & 74.93 \\
\hline Weed coverage^ ${ }^{\wedge}$ & 58.33 & 94.29 & 81.13 & 87.16 & 87.64 & 87.64 & 100 & 62.5 & 83.61 \\
\hline Septic Density^^ & 0 & 0.01 & 0 & 0.64 & 3.13 & 0.72 & 0.16 & 0 & 2.72 \\
\hline Average Parcel size & 30.08 & 59.76 & 104.21 & 16.26 & 8.39 & 4.93 & 14.4 & 57.48 & 2.44 \\
\hline Percent private ownership & 71.86 & 91.17 & 84.08 & 90.19 & 92.64 & 84.49 & 86.24 & 68.81 & 74.76 \\
\hline Percent public ownership/easements & 35.23 & 18.38 & 25.91 & 25.84 & 7.76 & 20 & 19.83 & 29.24 & 29.54 \\
\hline Impact ranking (1 denotes least, 9 denotes most) & 1 & 4 & 3 & 6 & 8 & 8 & & 2 & 9 \\
\hline Total acres & 5806 & 46317 & 19487 & 108441 & 39598 & 78844 & 29422 & 54042 & 28275 \\
\hline Wetland Acres & 1 & 23 & 168 & 2420 & 534 & 1608 & 304 & 746 & 25 \\
\hline
\end{tabular}

* per wetland acre

** miles per square mile of watershed

$\star \star * \%$ of acres with population density $>100$ persons

per square mile

$\star \star \star \star ~ \%$ of acres in residential, agricultural, industrial,

or commercial uses

$\wedge \%$ of sections with one or more noxious weeds

$\wedge$ \% of acres with septic density rating "high" 
wetland acreage (16.37\%) of any watershed with 100 or more wetland acres. The Smith Creek/Dry Creek pair, which ranked 2nd and 3rd in impacts, differed in their alteration percentages, with Smith Creek (the less impacted) having almost $8 \%$ of its acreage altered and Dry Creek only 3\%. We cannot say for certain this is not a reflection of incomplete mapping, but we believe it is likely attributable to the Smith Creek watershed wetlands being more concentrated on the floodplain.

We also used impact rankings to determine which wetland functions were most at risk in the study area as a whole. Johnson (2005) has made a useful distinction between impacts and effects, noting impacts are actions while effects are their results. Draining, ditching, or direct alteration of a wetland is an impact; loss of specific function is an effect. Although altered wetlands can still perform wetland functions (e.g. excavated wetlands can provide water storage, or habitat for ducks and fish), they generally do not perform at as high a level as unaltered wetlands in intact landscapes. A future project will examine the loss of wetland function in the Gallatin Valley over the past twentyplus years based on an HGM analysis of past and present wetland distribution and abundance. Here we are primarily concerned with identifying the functions at risk in watersheds where overall human impacts --that is, impacts at the wetland and whole-watershed level--are highest.

The Gallatin River-Gallatin Gateway, Lower East Gallatin, and Hyalite Creek watersheds contain $76 \%$ of the altered wetlands in the entire study area, but they also contain $78 \%$ of all the wetland acreage, so this is not particularly surprising. What we are concerned with here is the threat to the integrity of non-altered wetlands that is posed by more generalized impacts: road building, residential and commercial development, irrigation and other water withdrawals, the spread of noxious weeds, and so on. Assuming these sorts of generalized threats to wetland integrity are nearest at hand in those watersheds with the highest impact ratings, what are the watershed functions particular to their wetland profiles?
The watersheds with the highest impact rankings are the Lower East Gallatin, Hyalite Creek, and the Upper East Gallatin. Together, these watersheds hold $87 \%$ of Terrene Interfluve Basin wetlands, $71 \%$ of Terrene Interfluve Flat wetlands, and 33\% of all Terrene Basin wetlands. Because these types of wetlands typically rank high on nutrient cycling, sediment trapping, aquatic and terrestrial habitat and wetland biodiversity, it follows that those functions are at risk both within those watersheds and across the study area as a whole. Similarly, those three watersheds contain almost $40 \%$ of Lotic River Lower Gradient Floodplain wetlands, 36\% of Lotic River Lower Gradient Fringe Wetlands, and 39\% of Lotic Stream Lower Gradient Floodplain wetlands. Because these wetlands exist in other, somewhat less impacted watersheds (notably the Gallatin River-Gallatin Gateway and Lower Gallatin), their functions are somewhat less at risk across the study area as a whole. Nevertheless, we should consider surface water detention, stream maintenance, and plant community maintenance are at least moderately at risk in the study area. Furthermore, because these Lotic types, like the Terrene types, also have high function ratings for sediment trapping and aquatic/terrestrial habitat, these functions may be especially compromised in these three watersheds.

Impact rankings are not static, and as rankings, they are relative to each other. We do not have any reference standard watersheds in the study area against which impact scores could be calculated. The least impacted watershed with any significant wetland acreage, Smith Creek, still has over 51\% human land cover (based on the best available but 15 -year old land cover maps), almost 69\% private ownership, and noxious weeds in $63 \%$ of its sections. Wetland function may be less at risk in this watershed than in the Hyalite Creek watershed, but it is still at risk, and if development pressures continue to push new development into the foothills, impacts and risks will both increase.

\section{Evaluation of the Classification and Assessment Methodology}

GIS-based attribution of HGM descriptors was simple and efficient in the case of NWI Riverine 
System wetlands. Because these wetlands are by definition within an active channel, they were implicitly part of the HGM Lotic landscape position, which includes any wetlands within the active floodplain. USGS topo maps allowed rapid classification into Lotic River and Lotic Stream types, and the existence of a good soils layer allowed us to complete further assignment of floodplain wetlands without difficulty. The GIS approach began to have limitations when we attempted to assign landform. Palustrine Aquatic Bed wetlands were assumed to be depressional, and thus were attributed as Basin wetlands. We made the same assumptions about Palustrine Unconsolidated Bottom wetlands, but as these were all directly altered, they were classified as such (e.g. Terrene, Interfluve, Basin, Excavated). The attribution of landform to Palustrine Emergent, Scrub-shrub, and forested wetlands was more difficult. Most of these were classified as Lotic Stream or Lotic River Floodplain wetlands, or as Terrene Interfluve wetlands with no further landform descriptors, but the ones we inspected visually as part of our accuracy assessment were often given additional modifiers such as "Basin" or "Basin Oxbow," since these characteristics were clearly visible on the aerial photographs. Because oxbow wetlands have a notably high functional capacity in streamflow maintenance and water detention, the inability to identify these from a GIS alone should be considered a limitation of the approach. We also note the classification of Palustrine Emergent wetlands that were neither on a floodplain or an interfluve could only proceed beyond the "Terrene" classification with visual inspection. Approximately $15 \%$ of wetlands could not be classified at all with the GIS, primarily because of incomplete geomorphic information on the soils maps: it was unclear whether the underlying soils were or were not part of the floodplain until the aerial photographs were analyzed. In a subbasin with current 100-year floodplain maps, this would not have been an issue, and would have saved the step of drawing out a putative floodplain based on the soils maps.

Because almost all our wetlands were on the valley floor or the floodplain terrace of larger streams, we did not encounter slope wetlands and so did not refine our dichotomous key beyond its initial iteration. We caution the reader that this is a limitation of the key in future use.

We believe the assessment methodology shows great potential for future use. Because the study area has neither complete nor current maps, we did not attempt a highly detailed functional assessment that would integrate HGM and Palustrine types to tease out differences in functional capacity (e.g. between Lotic River Floodplain-Palustrine Scrub-Shrub wetlands and Lotic River FloodplainPalustrine Aquatic Bed wetlands). Similarly, because the National Land Cover Database is almost 15 years old, and does not capture the demographic change in the Gallatin Valley, we did not assess potential land use impacts to functions along wetland or stream corridors. However, with updated wetland and riparian maps, and edited (or newly generated) land cover layers, the combination of more detailed functional assessments and more focused impact assessments would yield a comprehensive coarse-scale evaluation of wetland function and condition. This is the direction we encourage in future work.

\section{Crosswalking between NWI, HGM and NVCS}

National Vegetation Classification System (NVCS) and other vegetation types (Hansen et al. 1995) were readily associated with USFWS types after our fieldwork in the Gallatin Valley, although the relationship was typically complex with several types possible for a USFWS type. Within NWI classes we also associated water regime modifiers with specific vegetation associations when possible. This result also allows an understanding of the considerable vegetation (and also the related habitat) diversity inherent within a type. For example, Palustrine Emergent wetlands have a high conservation of wetland biodiversity functional value in the HGM crosswalk due to the wide variety of vegetation associations potentially present.

The relationship between HGM and NWI types was also complex, especially in the case of the NWI Palustrine Class, and the HGM Lotic Class. 
Table 6 is a correspondence table showing the relationship between wetland classes (Appendix $\mathrm{B}$ contains the abbreviations used in the table). The NWI Palustrine Class has a one-to-many relationship with HGM types, including both Terrene and Lotic types, depending on their location and underlying soils. Similarly, although NWI Riverine Class wetlands are always HGM Lotic wetlands, HGM Lotic wetlands can be Riverine or Palustrine. In general, once the relationships were defined through repeated iterations, descriptive statistics, probability analyses and inspection of aerial photographs, the GIS-based key worked fairly well. However, it has not been tested beyond the Gallatin, and therefore we do not know how well it would work in areas with more high-gradient slopes and less floodplain development.

While the key did not allow us to produce a simple one-to-one crosswalk, the ability to attribute individual wetland polygons with HGM classifiers holds great promise for detailed wetland analyses that combine the best of both systems. In the field, we assigned specific HGM wetland functions to wetlands based on site-specific factors that could be discerned from observation of wetland composition, hydrologic relationships, and overall site condition. A similar kind of detailed connection is possible when a database includes both HGM and NWI attributes for specific polygons. For example, Lotic River Floodplain wetlands with thick forest coverage take up more nutrients than sparsely treed or semi-bare wetlands, but vegetation cannot be inferred from an HGM classification alone. When a particular polygon has both an NWI attribute and an HGM attribute, there is enough information to begin characterizing the degree to which a particular function is carried out by assigning weight values to modifiers or to attribute combinations. That type of detailed analysis was beyond the scope of the current study, but with additional research and field-testing, enhanced wetland databases would provide considerable assessment potential. We are attributing HGM types to NWI and riparian polygons now in our Bitterroot Valley mapping, so that would be an ideal starting point for advanced analysis.
Despite the complex relationship between classes, we were able to produce a guide to NWI types, functions and vegetation, reproduced in the next section. We recommend that work continues in the association of USFWS wetland and riparian types with NVCS vegetation types as mapping continues. Vegetation strongly influences habitat and many other ecological functions. Most land managers directly manage vegetation, so a linkage to the information rich NVCS with spatially explicit wetland/riparian mapping will be beneficial for many aspects of planning and management.

\section{Guide to National Wetlands Inventory Types and Functions}

We examined wetlands in the Gallatin Valley and reference literature to link the common NWI types to National Vegetation Classification System types, other vegetation types (Hansen et al. 1995), and Hydrogeomorphic (HGM) (Brinson 1993) wetland functions. While the HGM Approach is useful due to its focus on the functions of wetlands, there is no HGM mapping. Since NWI maps are available our goal was to associate HGM functions with NWI types to improve assessment and mitigation of wetlands in Montana. The association of NWI types with HGM types has proven useful in watershed-based wetland planning and evaluation in other areas (Tiner et al. 2000).

The NWI classification system is hierarchical with an increasing level of detail. Five broad Systems exist: Palustrine, Lacustrine, Riverine, Estuarine, and Marine. Only the first three exist in Montana. Lacustrine and Riverine Systems are further divided into Subsystems. For example, Lacustrine Systems may be Limnetic or Littoral; Riverine Systems may be Upper Perennial, Lower Perennial, Intermittent, etc. No Subsystems exist in the Palustrine System. Below Systems and Subsystems are Classes describing the substrate, and hydrologic modifiers describing the water regime. Accuracy of map coding decreases further down the classification system; hydrologic modifiers are the least accurate, especially in Montana with our periodic droughts. 
Table 6. Correspondence Table, NWI to HGM.

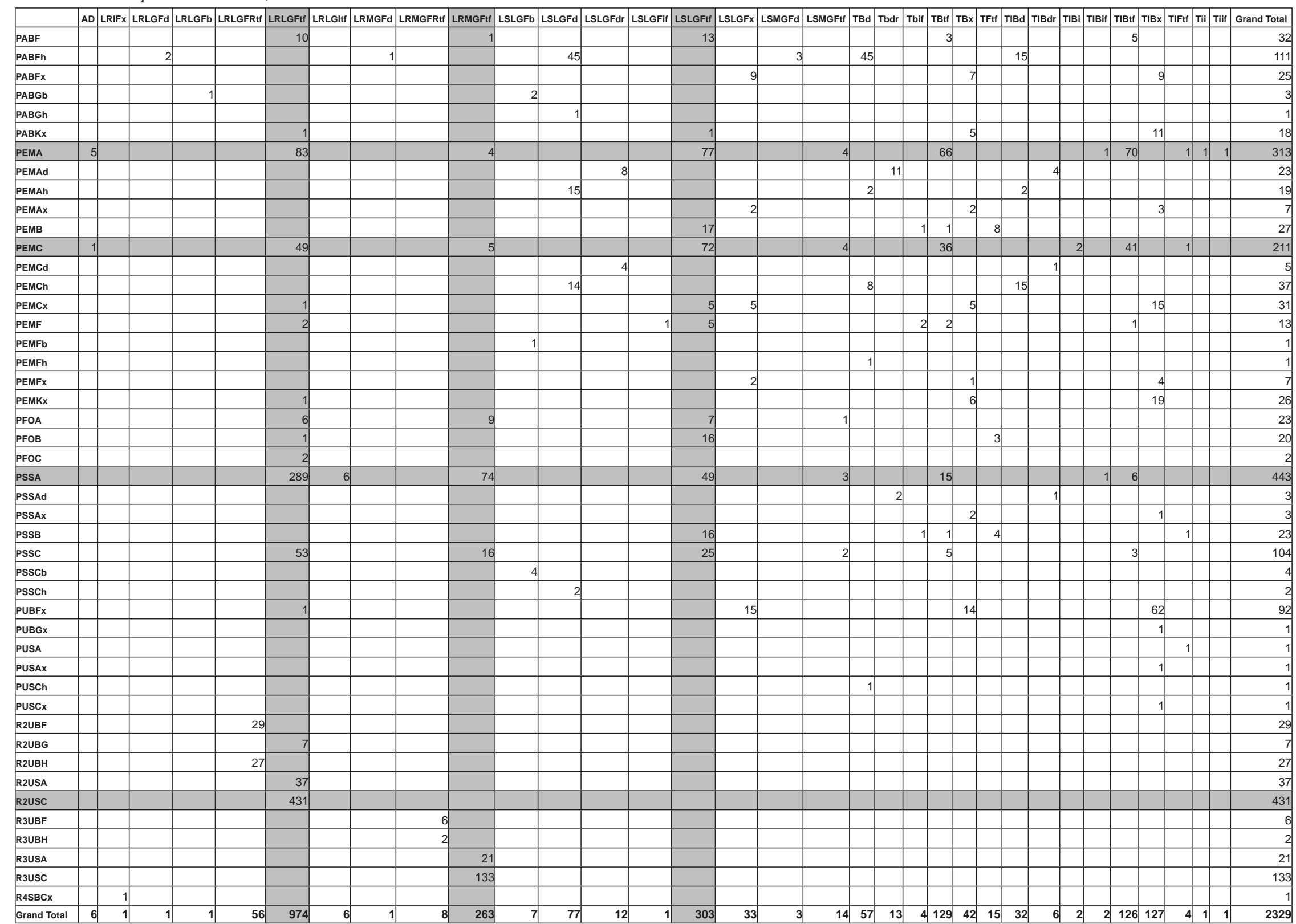

Highlighted columns indicate most common NWI or HGM classes in study area. 
Most Montana wetlands are Palustrine. This System includes any wetlands not within a stream or river channel (Riverine System) or within bodies of water which are either $>20$ acres OR deeper than 6.6 feet (Lacustrine System). See Cowardin et al. (1979) for complete details on the NWI classification system. Nine possible Classes in the Palustrine System exist. Five were common and sampled in the Gallatin Valley. Only one Riverine System was described.

The HGM Approach to wetland classification emphasizes wetland function, recognizing some wetlands perform certain hydrologic, habitat, or biochemical functions more effectively than others. We chose eight broad wetland functions, and evaluated the relative importance of each function for the common NWI types we sampled. The following crosswalk is specific to our study area in the Gallatin Valley, with applicability elsewhere depending on the similarity of environmental conditions.

\section{Palustrine System Unconsolidated Bottom Class (PUB), Aquatic Bed Class (PAB) \\ Summary}

The Unconsolidated Bottom Class has $<30 \%$ vegetation cover and a surface with $>25 \%$ of the particles smaller than stones. The closely related Aquatic Bed Class has $>30 \%$ vegetation cover of plants growing on or below the water's surface for most of the growing season in almost all years. Most of our wetlands in this class have a mix of silt, clay, and organic matter as substrate.

\section{Environment}

Typically found along watercourses in meander cutoffs (oxbows) and beaver ponds. The low vegetation cover is often due to relatively deep $(>.5 \mathrm{~m})$ and turbid water inhibiting a higher cover of emergent or submerged plants. In these situations, the hydrologic modifier will be "permanently flooded" but during years of drought, this may vary considerably.

\section{Vegetation}

These shallow ponds with silty bottoms usually have a concentric zone of emergent vegetation around the drier perimeter. See the Palustrine Emergent Vegetation System for a description of this vegetation. As the water depth increases to about $0.5 \mathrm{~m}$ typical emergents like cattail (Typha latifolia), sedges (Carex spp.), and bulrush (Scirpus and Schoenoplectus spp.) become very sparse and submerged plants become more abundant, including species of waterweed (Elodea spp.), watermilfoil (Myriophyllum spp.), bladderworts (Utricularia spp.), pondweeds (Potamogeton spp.) and Mare's tail (Hippuris vulgaris).

\section{Ecological Dynamics and Management Considerations}

Beavers are responsible for the formation of many of these wetlands, which may persist in this state for some period of time but will eventually drain or become filled with silt and transition to a different wetland or non-wetland environment. In mountainous landscapes, this type and the animals depending on it for habitat would be extremely rare without the beavers' dam-building activity. Floodplain dynamics create another typical setting for these ponds.

If river hydrology is altered, or if beaver activity ceases, existing types may fill in with sediment and new locations may not be created. If livestock have access to this type, they can degrade the habitat by trampling the vegetation, pugging the soft soil nearby, and exposing soil for weed colonization sites. As is true with all wetlands, maintaining the hydrology is key to the wetland; changes in the quality or quantity of water reaching the wetland will alter the vegetation and habitat values.

\section{Hydrogeomorphic Types and Functions} PUB and PAB wetlands correspond to several HGM types depending on location. In the NWI classification system, only those wetlands occurring within the stream or river channel are classified as Riverine. Wetlands occurring within the bankful channel and/or the active floodplain of a river or stream have a lotic landscape position; those surrounded by uplands have a terrene landscape 
position. Within the Gallatin sampling area, the PUB wetlands had a lotic landscape position when they were associated with beaver activity, or a terrene position when they were not on an active floodplain. The PAB wetlands we sampled were also typically beaver ponds, and so were classified as lotic river or stream. These are important habitats due to the dependable presence of water in most years, a rarity in much of our arid landscape. Amphibians and aquatic reptiles are especially dependent but waterfowl and numerous other creatures also need these wetlands. Table 7 shows the HGM classifications that can be associated with PUB and PAB wetlands.

Table 7. Typical HGM types associated with PAB/PUB wetlands

\begin{tabular}{|c|c|c|c|c|}
\hline $\begin{array}{l}\text { Landscape } \\
\text { Position }\end{array}$ & Landform & $\begin{array}{l}\text { Lotic Water Size } \\
\text { Modifier }\end{array}$ & $\begin{array}{l}\text { Lotic Flow } \\
\text { Regime }\end{array}$ & $\begin{array}{l}\text { Water Flow } \\
\text { Path }\end{array}$ \\
\hline 1. Terrene & \multirow[t]{2}{*}{$\begin{array}{l}\text { Depression } \\
\text { Floodplain }\end{array}$} & & & \multirow{2}{*}{$\begin{array}{l}\text { Bidirectional } \\
\text { Throughflow } \\
\text { Isolated } \\
\text { Inflow } \\
\text { Outflow }\end{array}$} \\
\hline 2. Lotic & & $\begin{array}{l}\text { River } \\
\text { Stream }\end{array}$ & $\begin{array}{l}\text { Dammed Reach } \\
\text { Low Gradient }\end{array}$ & \\
\hline
\end{tabular}

Table 8. Functions associated with PAB/PUB wetlands

\begin{tabular}{|l|l|l|}
\hline Function & $\begin{array}{l}\text { Relative } \\
\text { Importance }\end{array}$ & Comments \\
\hline $\begin{array}{l}\text { 1. Surface and } \\
\text { Groundwater } \\
\text { Strage and } \\
\text { Maintenance }\end{array}$ & $\begin{array}{l}\text { High to } \\
\text { Moderate }\end{array}$ & $\begin{array}{l}\text { Larger and deeper depressions are the most effective. Fine } \\
\text { textured and high organic content soils are better. Throughflow } \\
\text { water paths and terrene outflow wetlands are less effective. } \\
\text { Wetlands on higher order streams are more important. }\end{array}$ \\
\hline $\begin{array}{l}\text { 2. Nutrient } \\
\text { Cycling }\end{array}$ & High to Low & $\begin{array}{l}\text { Vegetated types have higher importance. Denitrification } \\
\text { is higher with organic substrates. A fluctuating water table } \\
\text { is best. High organic content and fine textured substrates } \\
\text { are most effective. Lotic wetlands are more important in } \\
\text { preserving water quality, especially on lower order streams. }\end{array}$ \\
\hline $\begin{array}{l}\text { 3. Maintain Plant } \\
\text { Community }\end{array}$ & $\begin{array}{l}\text { High to } \\
\text { Moderate } \\
\text { have little vegetation. Otherwise, a variety of water depths } \\
\text { create different vegetation zones for these distinctive plant } \\
\text { communities. }\end{array}$ \\
\hline $\begin{array}{l}\text { 4. Retention } \\
\text { of sediments, } \\
\text { elements, and } \\
\text { compounds }\end{array}$ & High to Low & $\begin{array}{l}\text { Terrene throughflow basins and most lotic wetlands other than } \\
\text { flats are the most effective. Ponds with a small watershed are } \\
\text { of low importance. Vegetated wetlands are more effective. }\end{array}$ \\
\hline $\begin{array}{l}\text { 5. Shoreline } \\
\text { Stabilization }\end{array}$ & Low & $\begin{array}{l}\text { Most of these types are ponds with little shoreline erosion } \\
\text { potential. }\end{array}$ \\
\hline $\begin{array}{l}\text { 6. Terrestrial } \\
\text { Habitat }\end{array}$ & $\begin{array}{l}\text { These water sources are critical for waterfowl and many other } \\
\text { animal species. }\end{array}$ \\
\hline
\end{tabular}


Table 8. Continued.

\begin{tabular}{|l|l|l|}
\hline 7. Aquatic Habitat & High & $\begin{array}{l}\text { Amphibian and aquatic reptile habitat value is high, especially } \\
\text { with deeper water depths. These types may also provide good } \\
\text { fish habitat. The long water retention time is important for } \\
\text { some macroinvertebrates. }\end{array}$ \\
\hline $\begin{array}{l}\text { 8. Conservation } \\
\text { of Wetland } \\
\text { Biodiversity }\end{array}$ & High & $\begin{array}{l}\text { These are relatively common types but the absence of beaver } \\
\text { could significantly diminish these occurrences. }\end{array}$ \\
\hline
\end{tabular}

Palustrine System Emergent Wetland Class (PEM)

Summary

This type is defined by the dominance of erect rooted herbaceous (not woody) wetland plants. If there is $>30 \%$ cover of woody plants, then the type would be Scrub-Shrub or Forested. There are a variety of water regimes influencing the soil, vegetation and habitat characteristics.

\section{Environment}

In the Gallatin Valley these wetlands were mostly associated with floodplains but were also occasionally found on subirrigated terraces. The floodplains range from seasonally inundated and perennially saturated at their wettest to merely seasonally subirrigated at their dry extreme. Landscape features include sloughs created by channel meanders, shorelines of oxbow lakes and drier or drained beaver ponds. While this community often occurs around the edges of beaver ponds, this fringe is typically too small to be mapped on NWI maps unless it is a very large pond. The more xeric riparian sites occur higher in the landscape and are inactive floodplains, terraces and toeslopes; these sites are primarily seasonally subirrigated and have high water tables receding below the rooting zone by mid to late summer.

\section{Vegetation}

Of communities with predominantly native plants, those dominated by beaked sedge (Carex utriculata) are the most common and exhibit the broadest range of water regime, from permanently flooded (oxbows and beaver ponds) to saturated and temporarily flooded. The Baltic rush (Juncus balticus) vegetation community is nearly as well represented. It exhibits a broad range of adaptability to water regimes, but does not occur under permanently flooded conditions. The woollyfruit sedge (Carex lanuginosa), slender sedge (C. lasiocarpa) and bluejoint reedgrass (Calamagrostis canadensis) vegetation communities represent a gradient (in wettest to driest order) from semi-permanently flooded, to saturated soil conditions to wet meadows experiencing mid- to late-summer drying below the rooting zone. On the driest surfaces, but still potentially wetland if subirrigated, is the western wheatgrass (Pascopyrum smithii) - green needlegrass (Nasella viridula) community. All these communities are typically dominated by the named species with only scattered other graminoids and forbs. In all but the western wheatgrass-green needlegrass community, the most common forbs are field mint (Mentha arvensis), large-leaved avens (Geum macrophyllum), water smartweed (Polygonum amphibium), curly dock (Rumex crispus), buckbean (Menyanthes trifoliata), western water hemlock (Cicuta douglasi), Canada thistle (Cirsium arvense), silverweed (Argentina anserina formerly Potentilla anserina) and purple cinquefoil (Potentilla palustris).

\section{Ecological Dynamics and Management Considerations}

Floodplain dynamics create the typical setting for these wetlands. Like all wetlands, maintaining the hydrology is key to maintaining the wetland; changes in the quality or quantity of water reaching the wetland will alter the vegetation and habitat values. When beaver activity is responsible for the formation of these wetlands, sites are quite dynamic and the community may transition to a different wetland or a non-wetland environment within fairly short time periods. As is true with PUB and PAB 
wetlands, beaver activity is especially important in mountainous landscapes where this type, and the habitat, would otherwise be rare.

If livestock have access to this Class, especially when the soils are wet, they can degrade the habitat by trampling the vegetation, pugging the soft soil, and exposing soil for weed colonization sites. We noted sheep found beaked sedge palatable both early in the growing season and post-growing season, but caused no perceptible compositional alteration in these perennially saturated sites. In the wettest sites with pugging from livestock, western water hemlock and silverweed were the most prolific increasers, but the natives still maintained dominance. At the drier end of the moisture gradient, disturbance of western wheatgrass communities can result in dominance by introduced pasture grasses including smooth brome (Bromus inermis), Kentucky bluegrass (Poa pratensis), timothy (Phleum pretense) and Canada bluegrass ( $P$. compressa). Perhaps the condition most favorable to exotic introduction is created when flooding deposits fresh alluvium and seeds or other propagules are water- or wind-borne.
Canada thistle and spotted knapweed (Centaurea biebersteinii) are common invaders on these fresh sites.

\section{HGM types and modifiers}

The Palustrine Emergent Wetland class is found on active floodplains and terraces. Floodplain PEM wetlands in the Gallatin sampling area were typically Lotic River, Middle Gradient, Floodplain wetlands (Tables 9 and 10). When these Floodplain wetlands had a Throughflow water regime, Baltic rush communities were most common; when the water regime was Inflow, beaked sedge and woollyfruit sedge were more characteristic.

We also saw PEM wetlands along the edges of beaver ponds, oxbows, or other dammed streams; these corresponded to Lotic Stream, Dammed Reach, Fringe Wetlands with Bidirectional water regimes but were often too small to map. Cattail (Typha latifolia) dominated these types. When PEM wetlands were not on floodplains, they corresponded to Terrene, Slope, Throughflow HGM types. Both were typically dominated by beaked sedge, although woollyfruit sedge, slender sedge and Baltic rush communities were also found.

Table 9. Typical HGM types associated with PEM wetlands.

\begin{tabular}{|l|l|l|l|l|}
\hline $\begin{array}{l}\text { Landscape } \\
\text { Position }\end{array}$ & Landform & $\begin{array}{l}\text { Lotic Water Size } \\
\text { Modifier }\end{array}$ & $\begin{array}{l}\text { Lotic Flow } \\
\text { Regime }\end{array}$ & $\begin{array}{l}\text { Water Flow } \\
\text { Path }\end{array}$ \\
\hline 1. Terrene & & & & \\
& $\begin{array}{l}\text { Depression } \\
\text { Floodplain } \\
\text { Fringe } \\
\text { Slope }\end{array}$ & $\begin{array}{l}\text { River } \\
\text { 2. Lotic }\end{array}$ & $\begin{array}{l}\text { Bidirectional } \\
\text { Throughflow } \\
\text { Isolated }\end{array}$ \\
\cline { 3 - 4 } & & $\begin{array}{l}\text { Dammed Reach } \\
\text { Low Gradient } \\
\text { Moderate Gradient }\end{array}$ & $\begin{array}{l}\text { Inflow } \\
\text { Outflow }\end{array}$ \\
\hline
\end{tabular}

Table 10. Functions associated with PEM wetlands.

\begin{tabular}{|l|l|l|}
\hline Function & $\begin{array}{l}\text { Relative } \\
\text { Importance }\end{array}$ & Comments \\
\hline $\begin{array}{l}\text { 1. Surface and } \\
\text { Groundwater }\end{array}$ & $\begin{array}{l}\text { High to } \\
\text { Storage and }\end{array}$ & $\begin{array}{l}\text { Larger and deeper depressions are the most effective but with } \\
\text { greater depth emergent vegetation will disappear. Fine textured } \\
\text { Maintenance }\end{array}$ \\
& & $\begin{array}{l}\text { and high organic content soils are better. Throughflow water } \\
\text { paths and terrene outflow wetlands are less effective for storage. } \\
\text { Wetlands on higher order streams are more important. }\end{array}$ \\
\hline
\end{tabular}


Table 10. Continued.

\begin{tabular}{|l|l|l|}
\hline 2. Nutrient Cycling & $\begin{array}{l}\text { High to } \\
\text { Moderate }\end{array}$ & $\begin{array}{l}\text { Denitrification is higher with more organic material in the } \\
\text { substrate. Fine textured substrates are more effective than coarse } \\
\text { substrates. A fluctuating water table is best. Lotic wetlands are } \\
\text { more important in preserving water quality, especially on lower } \\
\text { order streams. }\end{array}$ \\
\hline $\begin{array}{l}\text { 3. Maintain Plant } \\
\text { Community }\end{array}$ & High to Low & $\begin{array}{l}\text { A variety of water depths will create different vegetation zones } \\
\text { for these distinctive plant communities. Can be dominated by } \\
\text { nonnative vegetation. }\end{array}$ \\
\hline $\begin{array}{l}\text { 4. Retention } \\
\text { of sediments, } \\
\text { elements, and } \\
\text { compounds }\end{array}$ & High to Low & $\begin{array}{l}\text { Terrene throughflow basins and lotic wetlands are the most } \\
\text { effective. Depressions with a small watershed are low importance. }\end{array}$ \\
\hline $\begin{array}{l}\text { 5. Shoreline } \\
\text { Stabilization }\end{array}$ & High to Low & $\begin{array}{l}\text { Most important in Lotic positions with higher water gradients and } \\
\text { throughflow water paths. }\end{array}$ \\
\hline $\begin{array}{l}\text { 6. Terrestrial } \\
\text { Habitat }\end{array}$ & $\begin{array}{l}\text { High to } \\
\text { Moderate } \\
\text { uplands providing cover and food for many species. Waterfowl } \\
\text { and other birds use this habitat. }\end{array}$ \\
\hline $\begin{array}{l}\text { 7. Aquatic Habitat } \\
\text { 8. Conservation } \\
\text { of Wetland } \\
\text { Biodiversity }\end{array}$ & High to Low & $\begin{array}{l}\text { Amphibian and aquatic reptile habitat value can be high with } \\
\text { deeper water depths. These types may also provide fish habitat. }\end{array}$ \\
\hline
\end{tabular}

\section{Palustrine System Scrub-Shrub} Wetland Class (PSS)

\section{Summary}

This type is defined by $>30 \%$ canopy cover of shrubs or small trees $<6 \mathrm{~m}$ (20 ft.) in height. All water regimes except subtidal and permanently flooded are potentially included, but Montana types are, in approximate order of extent: saturated, seasonally flooded, temporarily flooded and semipermanently flooded. The semipermanently flooded condition is especially common in areas where beavers have been active. Although all four subclasses (Broad-leaved Deciduous, Broad-leaved Evergreen, Needle-leaved Evergreen and Dead) occur within Montana, the Broad-leaved Deciduous Subclass was the only sampled subclass in the Gallatin Valley and is the typical Subclass across the state, even in mountainous terrain.

\section{Environment}

These types are most common in floodplain environments, often where deposition on inside curves creates sand or gravel bars quickly colonized by shrubs and trees. The drier fringes of beaver ponds and oxbows can also have this type, although these are often too small in area to be mapped in NWI mapping.

\section{Vegetation}

The most abundant Scrub-Shrub types in the Gallatin Valley are dominated by sandbar willow (Salix exigua). These can vary from a dense bed of seedlings on recently deposited alluvium, which probably will be exposed to seasonal flooding for a number of years, to a sapling class or a mature stand approaching $5 \mathrm{~m}$ (16 ft.) in height in which other willow (Salix spp.) and cottonwood and aspen (Populus spp.) species are well established with a saturated to temporarily flooded water regime. Three other common early successional willow species (Salix spp.), Pacific willow (S. lucida ssp. lasiandra), yellow willow (S. lutea), and Bebb willow (S. bebbiana), may co-occur with sandbar willow, or in any mix with one another, or be sole community dominants. Other than sandbar 
willow only Pacific willow appears capable of colonizing raw gravel bars.

The undergrowth dominants of these stands range from beaked sedge (Carex utriculata) on the wettest of sites, to bluejoint reedgrass (Calamagrostis canadensis) and tufted hairgrass (Deschampsia cespitosa) on sites saturated to the surface but seldom flooded, to smooth brome (Bromus inermis), Kentucky bluegrass (Poa pratensis) and, in the uncommon instances of native dominance, western wheatgrass (Pascopyrum smithii) on the driest sites. Reed canarygrass (Phalaris arundinacea) and fowl bluegrass (Poa palustris) have a broad tolerance range of water regime and degree of shading. Although both are exotics, there is no indication disturbance (beyond what is expected in riparian systems) is necessary for their introduction or maintenance. Reed canarygrass is a very aggressive colonizer capable of forming a virtually monospecific undergrowth.

Although the western snowberry (Symphoricarpos occidentalis) community type is quite abundant in the riparian zone on alluvial floodplain terraces, only one wetland site, probably subirrigated or temporarily flooded, was identified. This type is often not considered wetland or even riparian but occurs more typically in upland swales (Hansen et al. 1995). It has the potential to support western wheatgrass, green needlegrass (Nasella viridula) and a variety of native herbs, but is more typically dominated by exotic grasses including quackgrass (Agropyron repens), smooth brome (Bromus inermis), Kentucky bluegrass (Poa pratensis) and timothy (Phleum pratense). Wood's rose (Rosa woodsii) also may attain high coverages. Only the very wettest margin of this type seems capable of supporting the otherwise ubiquitous reed canarygrass.

Alder (Alnus incana) communities were often associated with beaver activity, both old and new. Beaver activity (as a disturbance) did not result in the establishment of these stands; rather they occupy floodplain terraces, which may have experienced ice jam phenomena in the past. Most stands observed during the field season of 2005 are currently sufficiently removed from the main channel to make ice scour a remote probability. The Gallatin Valley occurrences had a strong component of willows (Bebb willow and Pacific willow), and willow-dominated community types were intermingled with mountain alder stands. Narrowleaf cottonwood (Populus angustifolia) is scattered in the stands or occurs nearby and will probably become the canopy dominant. Wellbrowsed red-osier dogwood (Cornus sericea) is often present in the mid-shrub layer. Stands adjacent to beaver ponds and semipermanent flooding are dominated by beaked sedge in the herbaceous layer. Higher positions, although continuously saturated, have bluejoint reedgrass, redtop (Agrostis stolonifera), reed canarygrass and drooping woodreed (Cinna latifolia) as dominants of the herbaceous layer, with the most constant forb being the obligate wetland species western water hemlock (C. douglasii).

\section{Ecological Dynamics and Management Considerations}

Where the floodplain is relatively narrow, succession may not progress beyond a Scrub-Shrub wetland before the watercourse meanders back, eroding the bank where a shrub- or tree- dominated stand was developing. Young stands of cottonwood would also be in the Scrub-Shrub Wetland Class; with continued development they would grow into the Forest Wetland Class. Some willow communities, especially those dominated by Pacific willow, also transition to Forest Wetlands.

Floodplain dynamics create the typical setting for these wetlands. Like all wetlands, maintaining the hydrology is key to maintaining the wetland; changes in the quality or quantity of water reaching the wetland will alter the vegetation and habitat values, and new locations may not be created. When beavers are responsible for the formation, sites are quite dynamic and the community may transition to a different wetland or a non-wetland environment within fairly short time periods. Beavers are especially important in mountainous landscapes where this type, and the habitat, would be extremely rare without their dam-building activity. 
If livestock have access to this type, especially when the soils are wet, they can degrade the habitat by trampling the vegetation, pugging the soft soil, and exposing soil for weed colonization sites. Perhaps the condition most favorable to exotic introduction is created when flooding deposits fresh alluvium, and seeds or other propagules are delivered water or wind-borne.

\section{HGM types and modifiers}

Most of the Shrub-Scrub wetlands in our sampling area are Lotic River or Stream, Low to Middle Gradient Floodplains (Tables 11 and 12). Sandbar willow communities were most characteristic of the Lotic River or Stream, Middle Gradient Inflow wetlands. Lotic River Throughflow types often have alder as the dominant. Bebb willow was typical of Low Gradient Lotic Stream wetlands. On some of the alluvial bars associated with Lotic Stream, Middle Gradient, wetlands, young narrowleaf cottonwoods were establishing.

Beyond the active floodplain, Palustrine scrubshrub wetlands were likely to be Terrene Floodplain or Slope Wetlands with Throughflow water regimes. Early successional shrubs like yellow willow with a beaked sedge understory dominated the Terrene Floodplain wetlands. Slope wetlands had alder, Pacific willow or yellow willow as dominants.

Table 11. Typical HGM types associated with PSS wetlands.

\begin{tabular}{|c|c|c|c|c|}
\hline $\begin{array}{l}\text { Landscape } \\
\text { Position }\end{array}$ & Landform & $\begin{array}{l}\text { Lotic Water Size } \\
\text { Modifier }\end{array}$ & $\begin{array}{l}\text { Lotic Flow } \\
\text { Regime }\end{array}$ & $\begin{array}{l}\text { Water Flow } \\
\text { Path }\end{array}$ \\
\hline 1. Terrene & \multirow{3}{*}{$\begin{array}{l}\text { Depression } \\
\text { Floodplain } \\
\text { Slope }\end{array}$} & & & \multirow{3}{*}{$\begin{array}{l}\text { Bidirectional } \\
\text { Throughflow } \\
\text { Isolated } \\
\text { Inflow } \\
\text { Outflow }\end{array}$} \\
\hline & & & & \\
\hline 2. Lotic & & $\begin{array}{l}\text { River } \\
\text { Stream }\end{array}$ & $\begin{array}{l}\text { Dammed Reach } \\
\text { Low Gradient } \\
\text { Moderate Gradient }\end{array}$ & \\
\hline
\end{tabular}

Table 12. Functions associated with PSS wetlands.

\begin{tabular}{|l|l|l|}
\hline Function & $\begin{array}{l}\text { Relative } \\
\text { Importance }\end{array}$ & Comments \\
\hline $\begin{array}{l}\text { 1. Surface and } \\
\text { Storage and } \\
\text { Streamflow } \\
\text { Maintenance }\end{array}$ & High to Low & $\begin{array}{l}\text { Fine textured and high organic content soils are better. } \\
\text { Throughflow water paths and terrene outflow wetlands are less } \\
\text { effective. Wetlands on higher order streams are more important. } \\
\text { Many of these types are on coarse soils near watercourses and } \\
\text { will not rate highly for this function. }\end{array}$ \\
\hline 2. Nutrient Cycling & High to Low & $\begin{array}{l}\text { Denitrification is higher with more organic material in the } \\
\text { substrate. Fine textured substrates are more effective than the } \\
\text { coarse substrates that most of these types have. A fluctuating } \\
\text { water table is best. Lotic wetlands are more important in } \\
\text { preserving water quality, especially on lower order streams. }\end{array}$ \\
\hline $\begin{array}{l}\text { 3. Maintain Plant } \\
\text { Community }\end{array}$ & $\begin{array}{l}\text { High to } \\
\text { Moderate }\end{array}$ & \begin{tabular}{l} 
The understory can be dominated by nonnative vegetation. \\
\hline
\end{tabular} \\
\hline
\end{tabular}


Table 12. Continued.

\begin{tabular}{|l|l|l|}
\hline $\begin{array}{l}\text { 4. Retention } \\
\text { of sediments, } \\
\text { elements, and } \\
\text { compounds }\end{array}$ & High to Low & $\begin{array}{l}\text { Terrene throughflow basins and lotic wetlands are the most } \\
\text { effective. Depressions with a small watershed are low importance. }\end{array}$ \\
\hline $\begin{array}{l}\text { 5. Shoreline } \\
\text { Stabilization }\end{array}$ & $\begin{array}{l}\text { High to } \\
\text { Moderate }\end{array}$ & $\begin{array}{l}\text { Most important in Lotic positions with higher water gradients and } \\
\text { throughflow water paths. Shrubs typically have erosion resistant } \\
\text { root systems that are important for bank stabilization. }\end{array}$ \\
\hline $\begin{array}{l}\text { 6. Terrestrial } \\
\text { Habitat }\end{array}$ & High & $\begin{array}{l}\text { Especially important for birds but other species also rely on the } \\
\text { dense cover and the food resource some shrub species offer. } \\
\text { Important food source for beavers. }\end{array}$ \\
\hline 7. Aquatic Habitat & $\begin{array}{l}\text { Moderate to } \\
\text { Low }\end{array}$ & $\begin{array}{l}\text { Can provide some stream shading and woody debris in Lotic } \\
\text { positions. }\end{array}$ \\
\hline $\begin{array}{l}\text { 8. Conservation } \\
\text { of Wetland } \\
\text { Biodiversity }\end{array}$ & $\begin{array}{l}\text { Lowerate to } \\
\text { Lowese are relatively common types but some have been impacted } \\
\text { by improper grazing regimes. }\end{array}$ \\
\hline
\end{tabular}

\section{Palustrine System Forested Wetland}

\section{Class (PFO)}

\section{Summary}

This type has woody vegetation $>6 \mathrm{~m}$ (20 ft.) in height with $>30 \%$ canopy cover. The Broad-leaved Deciduous, Needle-leaved Evergreen and Dead are the only Subclasses present in Montana. In the Gallatin Valley only Broad-leaved Deciduous types are present. Potentially all water regimes, except subtidal and permanently flooded, are included, but in the Gallatin Valley only the temporarily flooded and saturated regimes were associated with this class.

\section{Environment}

The most common landform is floodplains where seedlings of narrowleaf cottonwood (Populus angustifolia) and/or Pacific willow (S. lucida ssp. lasiandra) establish on recently deposited alluvium.

\section{Vegetation}

Willows typically establish at the same time as the tree seedlings and dominate the stand until the slower growing trees overtop the shrubs. In the Gallatin Valley we sampled narrowleaf cottonwood / red osier dogwood (Cornus sericea) and narrowleaf cottonwood / herbaceous vegetation communities. In the first community red-osier dogwood is indicative of the type, but rose species (Rosa spp.) and western snowberry (Symphoricarpos occidentalis) may have greater canopy cover. The herbaceous component includes redtop (Agrostis stolonifera), reed canarygrass (Phalaris arundinacea), large-leaved avens (Geum macrophyllum) and Canada thistle (Cirsium arvense) with low to moderate cover; we have noted stands where reed canarygrass has become abundant (> 25\% cover) and dominant. The narrowleaf cottonwood / herbaceous vegetation type is a default type (Hansen et al. 1995) only defined by having $<25 \%$ shrub cover representing a severely disturbed secondary succession stage of other community types. The undergrowth in the Gallatin Valley included smooth brome (Bromus inermis), Kentucky bluegrass (Poa pratensis), timothy (Phleum pratense), quackgrass (Agropyron repens), and western wheatgrass (Pascopyrum smithii). Reed canarygrass is present in small patches, suggesting these stands are at the dry extreme of this species moisture tolerance. The noxious weeds leafy spurge (Euphorbia esula), knapweeds (Centaurea spp.), and Canada thistle (Cirsium arvense) can be common, especially in openings.

\section{Ecological Dynamics and Management Considerations}

Floodplain dynamics create the typical setting for these wetlands. River hydrology has been altered 
through dams on many rivers, and the floods creating tree regeneration sites may no longer occur. Like all wetlands, maintaining the hydrology is key to maintaining the wetland; changes in the quality or quantity of water reaching the wetland will alter the vegetation and habitat values.

If livestock have access to this type, especially when the soils are wet, they can degrade the habitat by trampling the vegetation, pugging the soft soil, and exposing soil for weed colonization sites. Livestock are active browsers of some of the shrubs native to these habitats and, along with trampling, can eliminate or change the composition of the shrub layer.

These floodplain locations are particularly vulnerable to colonization by invasive plant species due to the regular disturbance of soil and the deposition of seeds or other propagules by floodwaters. These stands often have a herbaceous layer almost totally composed of nonnative species.

Stream meander can place older stands in close proximity to the active channel. There can be active erosion that may eventually eliminate some or all of the stand.

\section{HGM types and modifiers}

In the Gallatin Valley wetlands we surveyed, PFO wetlands were classified as Lotic River, Middle Gradient, Floodplain Wetlands with a Throughflow water regime (Tables 13 and 14).

Table 13. Typical HGM types associated with PFO wetlands.

\begin{tabular}{|l|l|l|l|l|}
\hline $\begin{array}{l}\text { Landscape } \\
\text { Position }\end{array}$ & Landform & $\begin{array}{l}\text { Lotic Water Size } \\
\text { Modifier }\end{array}$ & $\begin{array}{l}\text { Lotic Flow } \\
\text { Regime }\end{array}$ & $\begin{array}{l}\text { Water Flow } \\
\text { Path }\end{array}$ \\
\hline Lotic & Floodplain & $\begin{array}{l}\text { River } \\
\text { Stream }\end{array}$ & $\begin{array}{l}\text { Low Gradient } \\
\text { Moderate Gradient }\end{array}$ & Throughflow \\
\hline
\end{tabular}

Table 14. Functions associated with PFO wetlands.

\begin{tabular}{|l|l|l|}
\hline Function & $\begin{array}{l}\text { Relative } \\
\text { Importance }\end{array}$ & Comments \\
\hline $\begin{array}{l}\text { 1. Surface and } \\
\text { Groundwater } \\
\text { Storage and } \\
\text { Streamflow } \\
\text { Maintenance }\end{array}$ & $\begin{array}{l}\text { Moderate to } \\
\text { Low }\end{array}$ & $\begin{array}{l}\text { Trees will root deeply and transpire considerable water during the } \\
\text { growing season. Fine textured and high organic content soils are } \\
\text { better. }\end{array}$ \\
\hline 2. Nutrient Cycling & $\begin{array}{l}\text { High to } \\
\text { Moderate }\end{array}$ & $\begin{array}{l}\text { Denitrification is higher with more organic material in the } \\
\text { substrate. Fine textured substrates are more effective than coarse } \\
\text { substrates. A fluctuating water table is best. These Lotic wetlands } \\
\text { are important in preserving water quality, }\end{array}$ \\
\hline $\begin{array}{l}\text { 3. Maintain Plant } \\
\text { Community }\end{array}$ & $\begin{array}{l}\text { Moderate to } \\
\text { Low }\end{array}$ & $\begin{array}{l}\text { The understory is often dominated by nonnative vegetation and } \\
\text { the shrub understory may be absent or diminished. Many of these } \\
\text { stands are decadent and dying. Regeneration can be limited due to } \\
\text { altered hydrology. }\end{array}$ \\
\hline $\begin{array}{l}\text { 4. Retention } \\
\text { of sediments, } \\
\text { elements, and } \\
\text { compounds }\end{array}$ & $\begin{array}{l}\text { High to } \\
\text { Moderate }\end{array}$ & $\begin{array}{l}\text { These vegetated wetlands in floodplain locations are generally } \\
\text { effective for this function. }\end{array}$ \\
\hline
\end{tabular}


Table 14. Continued.

\begin{tabular}{|l|l|l|}
\hline $\begin{array}{l}\text { 5. Shoreline } \\
\text { Stabilization }\end{array}$ & High & $\begin{array}{l}\text { These trees with large woody root systems occur in settings with } \\
\text { high erosion potential and are very effective at stabilizing banks. }\end{array}$ \\
\hline $\begin{array}{l}\text { 6. Terrestrial } \\
\text { Habitat }\end{array}$ & High & $\begin{array}{l}\text { Especially important for birds and bats, particularly cavity } \\
\text { nesters. A variety of other species also rely on this habitat. } \\
\text { Important food source for beavers. }\end{array}$ \\
\hline 7. Aquatic Habitat & $\begin{array}{l}\text { Moderate to } \\
\text { Low }\end{array}$ & $\begin{array}{l}\text { Can provide some stream shading, woody debris, terrestrial insect } \\
\text { input as a food source and leaf drop as a nutrient source. }\end{array}$ \\
\hline $\begin{array}{l}\text { 8. Conservation } \\
\text { of Wetland } \\
\text { Biodiversity }\end{array}$ & High & $\begin{array}{l}\text { Non-wetland riparian forests are much more common. Both types } \\
\text { are in decline due to altered hydrologic regimes and invasion } \\
\text { from Russian olive and salt cedar. They have also been impacted } \\
\text { by improper grazing regimes so sites with good shrub structure } \\
\text { are relatively uncommon. }\end{array}$ \\
\hline
\end{tabular}

\section{Riverine System, Lower Perennial Unconsolidated Shore (R2US)}

\section{Summary}

This type is contained within a lower perennial river channel. An unconsolidated shore must have $<75 \%$ cover of stones or larger rock and $<30 \%$ canopy cover of vegetation other than pioneering plants. Water regime can be irregularly exposed, regularly flooded, irregularly flooded, seasonally flooded, temporarily flooded, intermittently flooded, saturated or artificially flooded. The Unconsolidated Bottom type is similarly defined but has a wetter water regime.

\section{Environment}

Riverine Systems occur within a lower perennial river channel and have a disturbance regime limiting the establishment of dense permanent vegetation. These locations experience periodic flood and ice scour. Fairly narrow streamside fringes, point bars and extensive braided gravel bars are the typical sites for this type.

\section{Vegetation}

By definition, vegetation is sparse. Vegetation can vary annually depending on the species of propagules reaching and establishing on a site since these environments are regularly disturbed, although some species may be able to persist like well-rooted woody species or reed canarygrass (Phalaris arundinacea). Although sparse overall, there can be relatively dense clumps of vegetation, usually willows (Salix spp.), narrowleaf cottonwood (Populus angustifolia) seedlings/saplings, and reed canarygrass (Phalaris arundinacea). Water knotweed (Polygonum amphibium), redtop (Agrostis stolonifera), and other herbs may occur. Knapweed (Centaurea spp. mostly spotted knapweed, C. biebersteinii), common mullein (Verbascus thapsus), leafy spurge (Euphorbia esula), Canada thistle (Cirsium arvense) and other weedy species are also rapid colonizers on the drier portions of these open sites. Most of these sites would be considered to have "sparse vegetation" (canopy cover $<10 \%$ ) in the National Vegetation Classification System (hence mostly unclassified).

\section{Ecological Dynamics and Management Considerations}

Floodplain dynamics create these wetland sites. River hydrology has been altered through dams on many rivers and the floods creating these sites may have changed in intensity or timing. Like all wetlands, maintaining the hydrology is key to maintaining the wetland; changes in the quality or quantity of water reaching the wetland will alter the vegetation and habitat values. These locations experience active change and the shape or existence of any specific site can vary annually.

These floodplain locations are particularly vulnerable to colonization by invasive plant species due to the regular disturbance of the substrate and 
the deposition of seeds or other propagules by floodwaters.

HGM types and modifiers

Wetlands classified as Riverine under the NWI system are always Lotic River or Lotic Stream
HGM types. In the Gallatin, R2US wetlands corresponded to Lotic River, Middle Gradient, Floodplain Wetlands with a Throughflow water regime (Tables 15 and 16).

Table 15. Typical HGM types associated with R2US wetlands.

\begin{tabular}{|l|l|l|l|l|}
\hline $\begin{array}{l}\text { Landscape } \\
\text { Position }\end{array}$ & Landform & $\begin{array}{l}\text { Lotic Water Size } \\
\text { Modifier }\end{array}$ & $\begin{array}{l}\text { Lotic Flow } \\
\text { Regime }\end{array}$ & $\begin{array}{l}\text { Water Flow } \\
\text { Path }\end{array}$ \\
\hline Lotic & Floodplain & $\begin{array}{l}\text { River } \\
\text { Stream }\end{array}$ & $\begin{array}{l}\text { Low Gradient } \\
\text { Moderate Gradient }\end{array}$ & Throughflow \\
\hline
\end{tabular}

Table 16. Functions associated with R2US wetlands.

\begin{tabular}{|l|l|l|}
\hline Function & $\begin{array}{l}\text { Relative } \\
\text { Importance }\end{array}$ & Comments \\
\hline $\begin{array}{l}\text { 1. Surface and } \\
\text { Groundwater } \\
\text { Storage and } \\
\begin{array}{l}\text { Streamflow } \\
\text { Maintenance }\end{array}\end{array}$ & Low & These typically coarse soils drain quickly. \\
\hline $\begin{array}{l}\text { 2. Nutrient Cycling } \\
\text { Low }\end{array}$ & Moderate to & $\begin{array}{l}\text { These Lotic wetlands are important in preserving water quality, } \\
\text { but the coarse soils are not ideal for this function. }\end{array}$ \\
\hline $\begin{array}{l}\text { 3. Maintain Plant } \\
\text { Community }\end{array}$ & $\begin{array}{l}\text { Low } \\
\text { establish. }\end{array}$ \\
\hline $\begin{array}{l}\text { 4. Retention } \\
\text { of sediments, } \\
\text { elements, and } \\
\text { compounds }\end{array}$ & $\begin{array}{l}\text { Low } \\
\text { 5. Shoreline } \\
\text { Stabilization }\end{array}$ & $\begin{array}{l}\text { Loderate to absent and nonnative species often } \\
\text { but the coarse soils are not well suited for retention of elements or } \\
\text { compounds. }\end{array}$ \\
\hline $\begin{array}{l}\text { 6. Terrestrial } \\
\text { Habitat }\end{array}$ & $\begin{array}{l}\text { Moderate to } \\
\text { Low }\end{array}$ & Shese types are eroded faster than vegetated types but they are \\
\hline $\begin{array}{l}\text { 7. Aquatic Habitat } \\
\text { the first line of defense for shore stabilization. }\end{array}$ \\
\hline $\begin{array}{l}\text { 8. Conservation } \\
\text { of Wetland } \\
\text { Biodiversity }\end{array}$ & Low & $\begin{array}{l}\text { Rocks and stones along the shoreline provide colonization } \\
\text { surfaces for macroinvertebrates; undercut banks provide shelter } \\
\text { for fish }\end{array}$ \\
\hline
\end{tabular}




\section{Conclusions and Recommendations}

Updated USFWS NWI and riparian mapping is underway in areas of Montana where funding is available. We recommend mapping in new areas continues to associate vegetation types with USFWS types, since the comprehensive, readily available information about these vegetation types will help those seeking to better understand or manage wetlands. Although this effort was confined to the Gallatin Valley, it represents a strong beginning in our efforts to accrue this information for Montana. We have also demonstrated that it is possible to use a GIS to attribute HGM classes to NWI-classified polygons, especially when the majority of wetlands occur on floodplain soil, and this permits a broad assessment of wetland function and potential impairment on a landscape scale. What we have not yet determined is the degree to which this approach can be used in other landscapes, even in Montana. Individually attributing HGM modifiers at a detailed level to NWI polygons during the mapping process represents a significant effort, but if dichotomous keys have to be modified for every landscape and leave enough uncertainty that 20 to $30 \%$ of wetlands still have to be individually classified, there may be little time savings in a GIS-based approach. In our new mapping efforts, we will analyze both methods to determine the costs and benefits of adding an HGM attribute to every NWI polygon, but whatever the outcome of that analysis, we recommend linking functions to NWI types continues in some form. Wetlands are valued (and regulated) because of their functions and associated values; connecting mapping with functions will aid wetland mitigation, restoration, conservation, and management. 


\section{Literature Cited}

Bridger Outdoor Science School. No date. A reference guide to water resources in the Gallatin Watershed. Available from the NRCS at: http://www.mt.nrcs.usda.gov/technical/ecs/ watersheds/galsourcebook/index.html

Brinson, M. M. (1993). "A hydrogeomorphic classification for wetlands,” Technical Report WRP-DE-4, U.S. Army Engineer Waterways Experiment Station, Vicksburg, MS. NTIS No. AD A270 053.

Brinson, M. M., B. L. Swift, R. C. Plantico, and J. S. Barclay. 1981. Riparian ecosystems: their ecology and status. U.S. Fish and Wildlife Service Biological Report 81, U.S. Government Printing Office, Washington, D. C.

Census 2000. Profile of General Demographic Characteristics. Gallatin County, Montana. U.S. Census Bureau, Washington, DC.

Cowardin, L.M., V. Carter, F.C. Golet, and E.T. LaRoe. 1979. Classification of Wetlands and Deepwater Habitats of the United States. U.S. Department of the Interior, Fish and Wildlife Service, Washington, D.C. FWS/OBS$79 / 31$.

Dahl, T. E. 1990. Wetland losses in the United States 1780's to 1980's. U.S. Department of Interior, Fish and Wildlife Service, Washington, D.C.

ESRI 2005. ArcGIS 9.1. ESRI Corporation, Redlands, CA.

Finch, D. M., and L. F. Ruggiero. 1993. Wildlife and biological diversity in the Rocky Mountains and northern Great Plains. Natural Areas Journal 13:191-203.

Gallatin Local Water Quality District. 2004. Wetland and Riparian Resource Assessment of the Gallatin Valley. Available from the Gallatin Local Water Quality Resource District.
Grossman D.H., Faber-Langendoen D., Weakley A.S., Anderson M., Bourgeron P., Crawford R., Goodin K., Landaal S., Metzler K., Patterson K.D., Pyne M., Reid M., and Sneddon L. 1998. International classification of ecological communities: terrestrial vegetation of the United States. Volume I, The National Vegetation Classification System: development, status, and applications. The Nature Conservancy: Arlington, VA.

Hansen, P. L., R. D. Pfister, K. Boggs, B. J. Cook, J. Joy and D. K. Hinckley. 1995. Classification and management of Montana's riparian and wetland sites. Miscellaneous Publication No. 54. Missoula, MT: University of Montana, School of Forestry, Montana Forest and Conservation Station. 646 pp.

Hauer, F. R., Bradley J. Cook, Michael C. Gilbert, Ellis J. Clairain, Jr., and R. Daniel Smith. 2002a. “A Regional Guidebook for Applying the Hydrogeomorphic Approach to Assessing Wetland Functions of Riverine Floodplains in the Northern Rocky Mountains," ERDC/EL TR-02-21, U.S. Army Engineer Research and Development Center, Vicksburg, MS.

Hauer, F. R., Bradley J. Cook, Michael C. Gilbert, Ellis J. Clairain, Jr., and R. Daniel Smith. 2002b. "A Regional Guidebook for Applying the Hydrogeomorphic Approach to Assessing Wetland Functions of Intermontane Prairie Pothole Wetlands in the Northern Rocky Mountains,” ERDC/ELTR-027, U.S. Army Engineer Research and Development Center, Vicksburg, MS.

Jankovsky-Jones, M., B. Benge, F. Fink, P. Guillory, and J. Olson. 1999a. Idaho interim functional assessment for low-gradient broad basin, groundwater fed, slope wetlands with spring fed riverine inclusion. Prepared by the Idaho Wetland Functional Assessment Committee. 17 pp. 
Jankovsky-Jones, M., B. Benge, F. Fink, P. Guillory, and J. Olson. 1999b. Idaho interim functional assessment for riverine wetlands on the floodplains of low- to moderate gradient, 2nd or 3rd order streams on fine textured substrates. Prepared by the Idaho Wetland Functional Assessment Committee. 18 pp.

Johnson, J.B. 2005. Hydrogeomorphic wetland profiling: An approach to landscape and cumulative impacts analysis. EPA/620/R05/001. U.S. Environmental Protection Agency, Washington, DC.

Keddy, P. A. 2000. Wetland ecology: principles and conservation. Cambridge University Press, Cambridge, U.K.

Montgomery, D.R. 1999. Process domains and the river continuum. Journal of the American Water Resources Association 35:397-410.

MVSP. 2003. Multivariate Statistics Package. Kovach Computing Services, Anglesey, Wales.

Patten, D. T. 1998. Riparian ecosystems of semiarid North America: diversity and human impacts. Wetlands 18:498-512.

Scott, M. L., S. K. Skagen, and M. F. Merigliano. 2003. Relating geomorphic change and grazing to avian communities in riparian forests. Conservation Biology 17:284-296.

Sheldon, D., T. Hruby, P. Johnson, K. Harper, A. McMillan, S. Stanley, E. Stockdale. August 2003 Draft. Freshwater Wetlands in Washington State Volume 1: A Synthesis of the Science. Washington State Department of Ecology Publication \# 03-06-016.

Tiner, R., M. Starr, H. Bergquist, and J. Swords. 2000. Watershed-based Wetland Characterization for Maryland's Nanticoke River and Coastal Bays Watersheds: A Preliminary Assessment Report. U.S. Fish \& Wildlife Service, National Wetlands Inventory (NWI) Program, Northeast Region, Hadley, MA. Prepared for the Maryland Department of Natural Resources, Coastal Zone Management Program (pursuant to National Oceanic and Atmospheric Administration award). NWI technical report.
Tiner, R.W. 2003a. Dichotomous Keys and Mapping Codes for Wetland Landscape Position, Landform, Water Flow Path, and Waterbody Type Descriptors. U.S. Fish and Wildlife Service, National Wetlands Inventory Program, Northeast Region, Hadley, MA. 44 pp.

Tiner, R.W. 2003b. Correlating Enhanced National Wetlands Inventory Data with Wetland Functions for Watershed Assessments: A Rationale for Northeastern U.S. Wetlands. U.S. Fish and Wildlife Service, National Wetlands Inventory Program, Region 5, Hadley, MA. 26 pp.

Western Regional Climate Center. 2006. Data available online at www.wrcc..dri.edu. 

Appendix A. Dichotomous Key for GIS-based Assignment of HGM Classifications to NWI Wetlands in the Gallatin Valley 



\section{Key A: Key to Wetland Landscape Position}

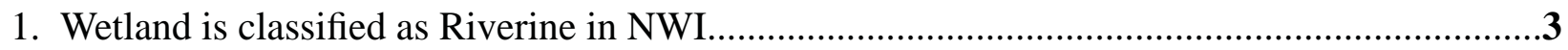

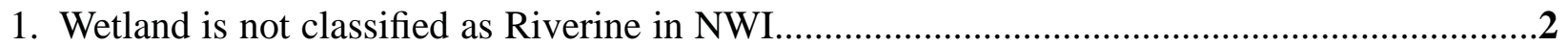

2. Wetland is completely or almost completely surrounded by upland soils...............Terrene (T)

Go to Key $B$ for inland landform

2. Wetland is completely or almost completely surrounded by floodplain soils.....

3. Wetland is associated with a stream (a linear or single-line watercourse on a 1:24,000 U.S.

Geological Survey topographic map)

Go to Couplet " $a$ ” below

$a$. Wetland is the source of a stream but this watercourse does not extend through the wetland.

Terrene (T)

Go to Key B for inland landform

a. Wetland is not the source of a stream or the watercourse extends through the wetland

Lotic Stream (LS)

Go to Couplet " $b$ " below

3. Wetland is associated with a river (a broad channel mapped as a polygon or 2-lined watercourse on a 1:24,000 U.S. Geological Survey topographic map)

Lotic River (LR)

Go to Couplet " $b$ " below

b. Stream or river associated with wetland is mapped as intermittent on a 1:24,000 USGS map.

Intermittent Gradient (IG)

Go to Key $D$ for water flow path

b. Stream is mapped as perennial on a 1:24,000 USGS map.

....C

c. Slope at site of wetland is greater than $4 \%$

.High Gradient (HG)

Go to Key $D$ for water flow path

c. Slope at site of wetland is less than $4 \%$ but more than $2 \%$..... Middle Gradient (MG)

Go to Key $D$ for water flow path

c. Slope at site of wetland is $2 \%$ or less

Low Gradient (LG)

Go to Key $D$ for water flow path

3. Wetland is classified as Lacustrine in the NWI.

Lentic (LE)

Go to Key C for Lake Type Then Go to Key B for inland landform

\section{Key B: Key to Inland Landforms}

1. Wetland is Terrene and occurs on slope $>4 \%$. Slope Wetland (SL)

Go to Key $D$ for water flow path

1. Wetland is not Terrene or occurs on a slope $<2 \%$.

2. Wetland is classified as Lacustrine in NWI or is classified as Riverine but is not completely surrounded by a 2-lined watercourse on a 1:24,000 USGS topo map......Fringe Wetland (FR)

Go to Key $D$ for water flow path

2. Wetland is not classified as Lacustrine in NWI 
3. Wetland is completely surrounded by water in a 2-lined watercourse on a 1:24,000 USGS topo map Island Wetland (I)

3. Wetland not as above. Go to Key $D$ for water flow path

4. Wetland is completely or almost completely surrounded by floodplain soils. Floodplain Wetland (F) Go to couplet 6 for further landform descriptors Then Go to Key $D$ for water flow path

4. Wetland is surrounded by upland soils or a mixture of upland and floodplain soils. . .5

5. Wetland occurs in a broad interfluve area between two rivers. Interfluve Wetland (I)

5. Wetland not as above. Go to Key $D$ for water flow path

6. Wetland exists in a distinct depression visible on aerial photos or a DEM, or is classified as a Palustrine Aquatic Bed or a Palustrine Unconsolidated Bed in NWI. Basin Wetland (B)

6. Wetland is not as above Flat Wetland (FL) Go to Key $D$ for water flow path

\section{Key C. Key to Lakes}

1. Waterbody is not dammed or impounded Natural Lake (1)

1. Waterbody is dammed, impounded, or excavated Dammed Lake

\section{Key D: Key to Water Flow Paths}

1. Wetland lies in the flow path of groundwater or surface water as determined from a DEM or NHD flowline, and that water appears to pass through the wetland to another wetland or waterbody at a lower elevation.....

1. Water does not pass through this wetland to other wetlands or waterbodies Throughflow (TF)

2. Water flows in and out of the waterbody through the same channel. Bidirectional (BI)

2. Water flow is not bidirectional.

3. There is no surface inflow or outflow to the wetland on NHD maps, and no inflow or outflow path is apparent on DEMs or aerial photos. Isolated (I)

3. Wetland is not hydrologically or geographically isolated.

4. Wetland lies in the flow path of groundwater or surface water as determined from a DEM or NHD flowline but no outflow flowline exists and no outflow path is apparent on DEMs or aerial photos .Inflow (IF)

4. Wetland does not lie in the flow path of groundwater or surface water as determined from a DEM or NHD but surface or ground water is discharged from this wetland to another wetland or water body at a lower elevation, as determined by an NHD flowline, a DEM or aerial photos .Outflow (OU) 
Appendix B. NWI and HGM Codes and Descriptions Used in This Report 



\begin{tabular}{|c|c|}
\hline NWI CODE & FULL DESCRIPTION \\
\hline PABF & Palustrine, Aquatic Bed, Semipermanently Flooded \\
\hline PABFh & Palustrine, Aquatic Bed, Semipermanently Flooded, Diked/Impounded \\
\hline PABFx & Palustrine, Aquatic Bed, Semipermanently Flooded, Excavated \\
\hline PABGb & Palustrine, Aquatic Bed, Intermittently Exposed, Beaver \\
\hline PABGh & Palustrine, Aquatic Bed, Intermittently Exposed, Diked/Impounded \\
\hline PABK $x$ & Palustrine, Aquatic Bed, Artificially Flooded, Excavated \\
\hline PEMA & Palustrine, E mergent, Temporarily flooded \\
\hline PEMAd & Palustrine, Emergent, Temporarily flooded, Partially Drained/Ditched \\
\hline PEMAh & Palustrine, Emergent, Temporarily flooded, Diked/Impounded \\
\hline PEMAX & Palustrine, Emergent, Temporarily flooded, Excavated \\
\hline PEMB & Palustrine, E mergent, Saturated \\
\hline PEMC & Palustrine, Emergent, Seasonally Flooded \\
\hline PEMCd & Palustrine, Emergent, Seasonally Flooded, Partially Drained/Ditched \\
\hline PEMCh & Palustrine, Emergent, Seasonally Flooded, Diked/Impounded \\
\hline PEMCX & Palustrine, Emergent, Seasonally Flooded, Excavated \\
\hline PEMF & Palustrine, Emergent, Semipermanently Flooded \\
\hline PEMFb & Palustrine, Emergent, Semipermanently Flooded, Beaver \\
\hline PEMFh & Palustrine, Emergent, Semipermanently Flooded, Diked/Impounded \\
\hline PEMFX & Palustrine, Emergent, Semipermanently Flooded, Excavated \\
\hline PEMKX & Palustrine, Emergent, Artificially F looded, Excavated \\
\hline PFOA & Palustrine, F orested, Temporarily flooded \\
\hline PFOB & Palustrine, Forested, Saturated \\
\hline PFOC & Palustrine, Forested, Seasonally Flooded \\
\hline PSSA & Palustrine, Scrub-Shrub, Temporarily flooded \\
\hline PSSAd & Palustrine, Scrub-Shrub, Temporarily flooded, Partially Drained/Ditched \\
\hline PSSAx & Palustrine, Scrub-Shrub, Temporarily flooded, Excavated \\
\hline PSSB & Palustrine, Scrub-Shrub, Saturated \\
\hline PSSC & Palustrine, Scrub-Shrub, Seasonally F looded \\
\hline PSSCb & Palustrine, Scrub-Shrub, Seasonally Flooded, Beaver \\
\hline PSSCh & Palustrine, Scrub-Shrub, Seasonally Flooded, Diked/Impounded \\
\hline PUBFx & Palustrine, Unconsolidated Bottom, Semipermanently Flooded, Excavated \\
\hline PUBGX & Palustrine, Unconsolidated Bottom, Intermittently Exposed, Excavated \\
\hline PUSA & Palustrine, Unconsolidated Shore, Temporarily flooded \\
\hline PUSAx & Palustrine, Unconsolidated Shore, Temporarily flooded, Excavated \\
\hline PUSCh & Palustrine, Unconsolidated Shore, Seasonally Flooded, Diked/Impounded \\
\hline PUSCX & Palustrine, Unconsolidated Shore, Seasonally Flooded, Excavated \\
\hline
\end{tabular}

Appendix $B$ - 1 


\begin{tabular}{|c|c|}
\hline NWI CODE & FULL DESCRIPTION \\
\hline R2UBF & Riverine, Lower Perennial, Unconsolidated Bottom, Semipermanently Flooded \\
\hline R2UBG & Riverine, Lower Perennial, Unconsolidated Bottom, Intermittently Exposed \\
\hline $\mathrm{R} 2 \mathrm{UBH}$ & Riverine, Lower Perennial, Unconsolidated Bottom, Permanently Flooded \\
\hline R2USA & Riverine, Lower Perennial, Unconsolidated Shore, Temporarily flooded \\
\hline R2USC & Riverine, Lower Perennial, Unconsolidated Shore, Seasonally Flooded \\
\hline R3UBF & Riverine, Upper Perennial, Unconsolidated Bottom, Semipermanently Flooded \\
\hline $\mathrm{R} 3 \mathrm{UBH}$ & Riverine, Upper Perennial, Unconsolidated Bottom, Permanently Flooded \\
\hline R3USA & Riverine, Upper Perennial, Unconsolidated Shore, Temporarily flooded \\
\hline R3USC & Riverine, Upper Perennial, Unconsolidated Shore, Seasonally Flooded \\
\hline R 4SBCX & Riverine, Intermittent, Streambed, Seasonally Flooded, Excavated \\
\hline HGM CODE & FULL DESCRIPTION \\
\hline$A D$ & Appears to have been drained \\
\hline LRIFx & Lotic River, Intermittent, Floodplain, Excavated \\
\hline LRLGFb & Lotic River, Lower Gradient, Floodplain, Dammed, Beaver \\
\hline LRLGFd & Lotic River, Lower Gradient, Floodplain, Diked/impounded \\
\hline LRLGFRtf & Lotic River, Lower Gradient, Fringe, Throughflow \\
\hline LRLGItf & Lotic River, Lower Gradient, Island, Throughflow \\
\hline LRMGF di & Lotic River, Middle Gradient, Floodplain, Diked/impounded \\
\hline LRMGFRtf & Lotic River, Middle Gradient, Fringe, Throughflow \\
\hline LSLGFb & Lotic Stream, Lower Gradient, Floodplain, Dammed, Beaver \\
\hline LSLGFd & Lotic Stream, Lower Gradient, Floodplain, Diked/impounded \\
\hline LSLGFdr & Lotic Stream, Lower Gradient, Floodplain, Drained/ditched \\
\hline LSLG F if & Lotic Stream, Lower Gradient, Floodplain, Inflow \\
\hline LSLGFtf & Lotic Stream, Lower Gradient, Floodplain, Throughflow \\
\hline LSLGFx & Lotic Stream, Lower Gradient, Floodplain, Excavated \\
\hline LSMGFd & Lotic Stream, Middle Gradient, Floodplain, Diked/impounded \\
\hline LSMGFtf & Lotic Stream, Middle Gradient, Floodplain, Throughflow \\
\hline TBd & Terrene, Basin, Diked/impounded \\
\hline TBdr & Terrene, Basin, Drained/ditched \\
\hline Thbif & Terrene, Basin, Inflow \\
\hline TBtf & Terrene, Basin, Throughflow \\
\hline TBx & Terrene, Basin, Excavated \\
\hline TFtf & Terrene, Flat, Throughflow \\
\hline TIBd & Terrene, Interfluve, Basin, Diked/impounded \\
\hline TIIBdr & Terrene, Interfluve, Basin, Drained/ditched \\
\hline
\end{tabular}

Appendix $B$ - 2 


\begin{tabular}{|ll|}
\hline HGM CODE & FULL DESCRIPTION \\
\hline TIBi & Terrene, Interfluve, Basin, Isolated \\
TIBif & Terrene, Interfluve, Basin, Inflow \\
TIBtf & Terrene, Interfluve, Basin, Throughflow \\
TIBX & Terrene, Interfluve, Basin, Excavated \\
TIFtf & Terrene, Interfluve, Flat, Throughflow \\
Tii & Terrene, Interfluve, Isolated \\
Tiif & Terrene, Interfluve, Inflow \\
\hline
\end{tabular}

Appendix B - 3 